\title{
Anchialine biodiversity in the Turks and Caicos Islands: New discoveries and current faunal composition
}

\author{
Brett C. Gonzalez (D) 18*, Alejandro Martinez (D) 2§, Jørgen Olesen (D) ${ }^{3}$, Sarit B. Truskey (D) ${ }^{1,5}$, \\ Lauren Ballou (D) ${ }^{6}$, Marc Allentoft-Larsen (D) ${ }^{4}$, Joost Daniels (D) ${ }^{7}$, Paul Heinerth ${ }^{8}$, \\ Mark Parrish ${ }^{9}$, Naqqi Manco ${ }^{10}$, Jon Ward ${ }^{11}$, Thomas M. Iliffe (D) ${ }^{6}$, Karen J. Osborn (D) ${ }^{1,7}$, \\ and Katrine Worsaae (D) ${ }^{4}$
}

${ }^{1}$ Smithsonian Institution, National Museum of Natural History, Department of Invertebrate Zoology, P.O. Box 37012, Washington D.C., USA

${ }^{2}$ Molecular Ecology Group, Water Research Institute, National Research Council of Italy, Largo Tonolli 50, 28922 Verbania Pallanza, Italy

${ }^{3}$ Natural History Museum, University of Copenhagen, Universitetsparken 15, Copenhagen $\varnothing$, Denmark

${ }^{4}$ Marine Biological Section, Department of Biology, University of Copenhagen, Universitetsparken 4, Copenhagen $\varnothing$, Denmark

${ }^{5}$ Marine Science Center, Northeastern University, Nahant, Massachusetts, USA

${ }^{6}$ Marine Biology Department, Texas A\&M University at Galveston, Galveston, Texas, USA

${ }^{7}$ Monterey Bay Aquarium Research Institute, Moss Landing, CA, USA

${ }^{8}$ Professional Technical Diver, Hudson, Florida, USA

${ }^{9}$ Big Blue Collective, Leeward Highway, Leeward Settlement, Turks and Caicos Islands

${ }^{10}$ Department of Environment and Coastal Resources, Grand Turk, Turks and Caicos Islands

${ }^{11}$ Dive Provo, Grace Bay Road, Grace Bay, Turks and Caicos Islands

\begin{abstract}
Lying at the southernmost point of the Lucayan Archipelago, the Turks and Caicos Islands are amongst the better studied localities for anchialine cave biodiversity. For nearly five decades, novel invertebrate fauna, comprised primarily of crustaceans, have been collected from these tidally influenced pools - but new findings are always on the horizon. Herein we present new records of crustaceans and annelids from anchialine blue holes and horizontal caves of the Turks and Caicos. These findings include two potentially new species of meiofaunal annelids and a new species of remipede collected from a shallow water cave pool. Our 2019 expedition additionally expands known faunal distributions for several taxa across the Caicos islands, and raises the biodiversity of the region to 35 species, 13 of them considered endemic. This is the first comprehensive faunal list for the anchialine systems in the Caicos Bank.
\end{abstract}

Keywords: $\quad$ subterranean fauna, anchialine, Polynoidae, Nerillidae, Remipedia

Received 10 March 2020; Revised 7 May 2020; Accepted 10 May 2020

Citation: Gonzalez B.C., Martínez A., Olesen J., Truskey S.B., Ballou L., Allentoft-Larsen M., Daniels J., Heinerth P., Parrish M., Manco N., Ward J., Iliffe T.M., Osborn K.J. and Worsaae K., 2020. Anchialine biodiversity in the Turks and Caicos Islands: New discoveries and current faunal composition. International Journal of Speleology, 49 (2), 71-86. Tampa, FL (USA) ISSN 03926672 https://doi.org/10.5038/1827-806X.49.2.2316

\section{INTRODUCTION}

Anchialine ecosystems are characterized as tidal, brackish water bodies with subterranean connections to the sea (Holthuis, 1973). Originally described as tidally influenced pools, cave diving explorations in the late $20^{\text {th }}$ century highlighted that these systems are often associated with extensive subterranean labyrinths (Stock et al., 1986; Iliffe, 2000, 2005). Biological research in anchialine systems continues to yield new and exciting taxa, of uncertain phylogenetic affinities, within classes, orders and families that are often found exclusively in anchialine caves (Iliffe, 1986, 2000). Some of these species are phylogenetically old, presumably colonizing the anchialine realm in the Tertiary (Iliffe, 2005), while others exhibit close affinities to deep sea groups (Gonzalez et al., 2018; Iliffe \& Alvarez, 2018) or represent highly modified members of otherwise interstitial lineages (Worsaae et al., 2004, 2019b; Martínez et al., 2016b).

Anchialine systems are known from the Caribbean, Mediterranean, Indo-Pacific and Atlantic islands including Bermuda, Canary Islands, Ascension and even Iceland (Iliffe et al., 1983; Iliffe \& Sarbu, 1990; Biernbaum, 1996; Kristjánsson \& Svavarsson, 2007; Martínez García et al., 2009; Pérez-Moreno et al., 2016). The most extensive of these systems in terms of density and size of subterranean passages occur 
in the Northern Caribbean, particularly in the Yucatán Peninsula (Alvarez et al., 2015), Cuba (Orghidan et al., 1973), Jamaica (Kornicker \& Iliffe, 1992) and Hispaniola (Trias et al., 1997) as well as in the adjacent Lucayan Archipelago, which includes the Bahamas and the Turks and Caicos Islands (Palmer, 1985).

The Turks and Caicos Islands (Fig. 1A), and the neighboring islands of the Bahamas, are known for their high number of cave adapted anchialine species, prime for scientific exploration (Botosaneanu, 2000). Anchialine water bodies in this karstic area are primarily accessed through blue holes and horizontal caves (Gregor, 1981), harboring a diverse community of locally endemic, cavelimited species dominated by crustaceans, annelids and other invertebrates (Kornicker \& Iliffe, 1985; Suárez-Morales \& Iliffe, 1996; Koenemann et al., 2007). The first cave adapted species reported from the Turks and Caicos were the shrimp Barbouria cubensis (von Martens, 1872) and Typhlatya garciai Chace, 1942, discovered in 1975 from easily accessible pools and karstic windows (Buden \& Felder, 1977). However, the majority of the diversity was not discovered until after 1982 once scientific cave divers started exploring the subterranean labyrinths (Bowman et al., 1985; Holsinger \& Yager, 1985; Kornicker \& Iliffe, 1985). We here provide an overview of these discoveries, which we further update with the results of our "2019 Caicos Caves III Expedition" with the aim of obtaining a comprehensive genetic collection of anchialine fauna across cave systems of the Turks and Caicos Islands. A prospective on the general state of knowledge, as well as on potential conservation issues of these ecosystems, are provided.

\section{MATERIALS AND METHODS}

\section{Geological settings of the Turks and Caicos Island}

The Caicos Islands are the emerged part of the Caicos Bank, the southernmost platform in the Lucayan Archipelago. This large shallow water bank is surrounded by waters reaching oceanic depths, with the present-day Caicos Islands being located along the northern and western margins. Strong easterly trade winds and resulting wind-wave agitation have promoted the development of oolitic sands in the shallow water interior of the platform (Dravis \& Wanless, 2008). Washed ashore on the islands, these oolitic sands have piled into Holocene and Pleistocene age ridges, oriented parallel to the shoreline and perpendicular to prevailing easterly trade winds. These shallow water carbonates that comprise the bank have been continuously depositing
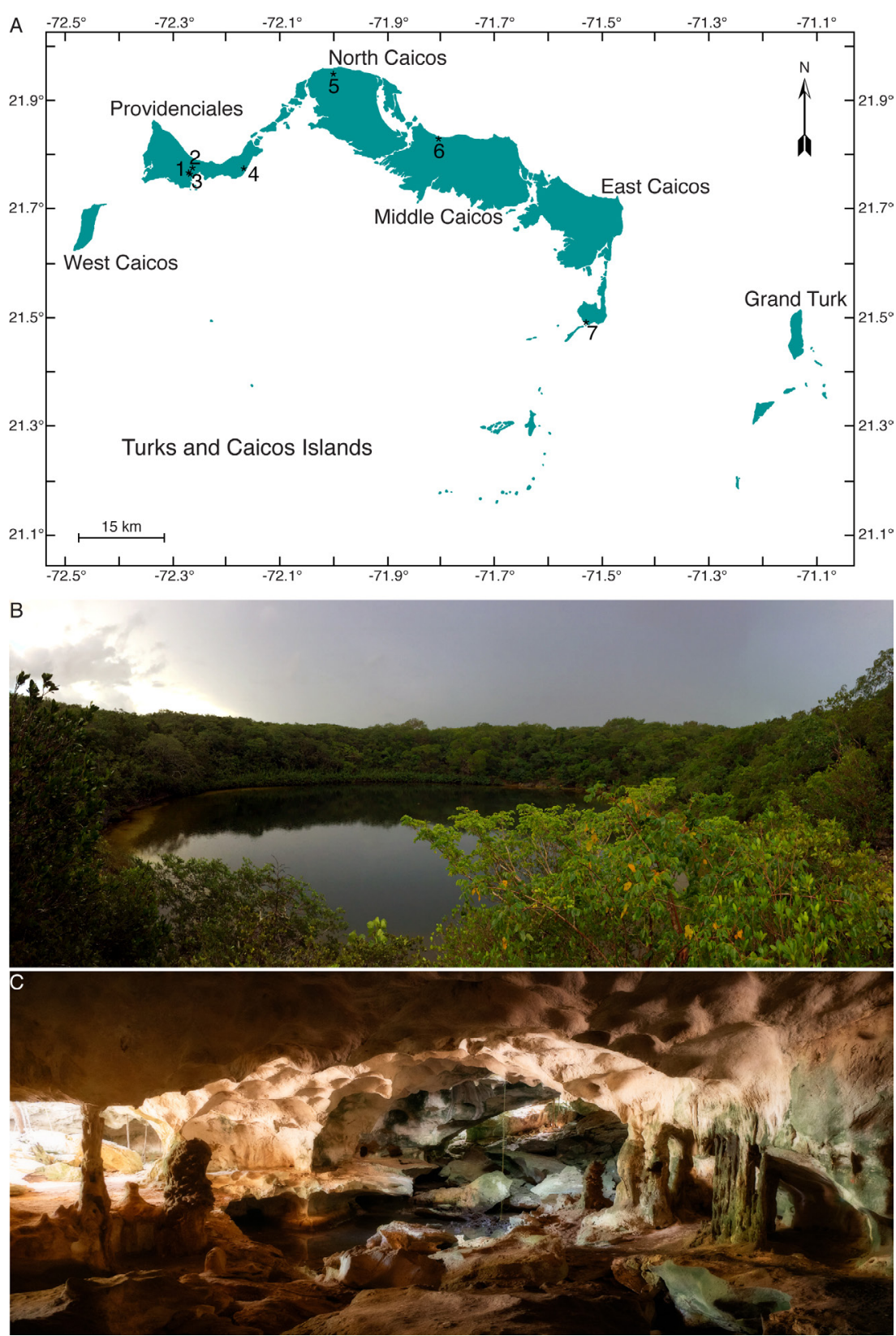

Fig. 1. The Turks and Caicos Islands with examples of cave systems found throughout the islands. A) Islands of the Turks and Caicos with known cave locations mapped: 6. Conch Bar Cave, 7. The Fountain; B) Cottage Pond, North Caicos Island. Photo by Brett C. Gonzalez; C) Conch Bar Cave, Middle Caicos Island. Photo by Joost Daniels

and subsiding since at least the Cretaceous, but possibly as early as the Jurassic (Schlager et al., 1984), and extend deep into the surrounding sea floor (Dietz et al., 1970). The slow subsidence of the bank due to the continually accumulating weight of new carbonates has maintained the top of the bank near sea level. Yet, during Pleistocene periods of sea level regressions, the entire top of the carbonate bank was exposed to atmospheric weathering, producing the characteristic karst terrain. The climate of the islands is tropical and semi-arid with an average temperature of $26^{\circ} \mathrm{C}$ and annual rainfall of $730 \mathrm{~mm}$. The karst topography of the islands is dominated by dolines (closed depressions) produced by limestone solution or collapse into underlying caves (Guidry et al., 2007). Collapsed caves on land consist of deep circular pits with a talus cone in the center, while occasional large vertical shafts or blue holes lie in shallow waters of the interior bank. Cavernous porosity underlying the 
islands resulted from dissolution along abundant fracture networks, running parallel to the bank margin (Guidry et al., 2007).

\section{History of previous cave expeditions}

The initial discovery of cave adapted aquatic fauna from the Caicos Islands occurred in April 1975 when Donald Buden collected the shrimp B. cubensis and T. garciai from several tidal cave pools on the island of Providenciales (Buden \& Felder, 1977). In November 1979, collections made during the Amsterdam Expeditions to the West Indian Islands resulted in the discovery and description of the amphipod Spelaeonicippe provo Stock \& Vermeulen, 1982. The first cave diving expedition, "Caicos Caves I", took place in October 1982, led by Thomas M. Iliffe, Jill Yager, Dennis Williams and Paul Hobbs. This trip was extraordinarily productive, yielding nine new cave adapted species: the annelid Pelagomacellicephala iliffei Pettibone 1985; copepod Erebonectoides macrochaetus (Fosshagen \& Iliffe, 1994); amphipod Bahadzia stocki Holsinger, 1985; leptostracan Speonebalia cannoni Bowman, Yager \& Iliffe, 1985; shrimp Agostocaris williamsi Hart \& Manning, 1986; ostracod Deeveya spiralis Kornicker \& Iliffe, 1985; remipedes Godzillius robustus Schram, Yager \& Emerson, 1986 and Kaloketos pilosus Koenemann, Iliffe \& Yager, 2004; and the stygiomysid Stygiomysis clarkei Bowman, Iliffe \& Yager, 1984. A year later, in October 1983, Williams found a third remipede, Lasionectes entrichoma Yager \& Schram, 1986. In May 1991, Iliffe collected the copepod Fosshagenia ferrarii Suarez-Morales \& Iliffe 1996. Twenty years after "Caicos Caves I", another significant diving expedition, "Caicos Caves II", took place in June 2003 and included Iliffe, Mark Parrish, John Garvin, James Hurley and Darcy Gibbons. This project discovered three new copepod species: Azygonectes plumosus Fosshagen \& Iliffe, 2007; Bofuriella spinose Fosshagen \& Iliffe, 2007; and Caiconectes antiquus Fosshagen \& Iliffe, 2007; a new isopod Bahalana caicosana Botosaneanu \& Iliffe, 2003; and another new remipede, Micropacter yagerae Koenemann, Iliffe \& van der Ham 2007. Most recently, in January 2019, the Smithsonian "Caicos Caves III" team consisted of Thomas M. Iliffe, Brett C. Gonzalez, Alejandro Martinez, Jørgen Olesen, Katrine Worsaae, Sarit Truskey, Lauren Ballou, Marc Allentoft-Larsen, Joost Daniels, Paul Heinerth and Rhonda Hart.

\section{Sampling collection - Smithsonian "Caicos Caves III"}

Our 2019 Caicos Caves III expedition was sponsored by the Smithsonian Institution with the aim of obtaining a comprehensive genetic collection of anchialine fauna across cave systems in the Turks and Caicos Islands. In order to accomplish this, fauna was unbiasedly collected across all available access points, including caves, ponds and wells with different environmental conditions, such as wideranging salinities (brackish to fully haline) and varying light exposure (entrance pools, twilight-, constant dark zones). Specific details pertaining to faunal collections are listed in Supplemental Table and detailed below.

Cave fauna was collected by scientific cave divers using $20 \mathrm{~mL}$ glass scintillation vials or $50 \mathrm{~mL}$ plastic falcon tubes. Prior to capture, water-filled vials and tubes were flushed with ambient cave water to prevent osmotic shock. For smaller fauna, plankton nets with removable cod-ends were employed (Iliffe $\&$ Alvarez, 2018). Separate cod-ends were used for fresh- and saltwater layers. Upon returning to the surface, samples were placed in lidded cooling boxes until processing. All samples were processed within 24-48 hrs.

Initial processing included photographing and assigning all samples museum voucher numbers. Live specimens were relaxed with an isotonic solution of $\mathrm{MgCl}_{2}$, then photographed using a mounted Canon EOS 5DSR with dual-slave Speedlite 430EX II strobes. Morphological examinations were done with light microscopy (LM) using Olympus SZX10 and SZX16 microscopes (Olympus, Tokyo, Japan).

Since the primary focus of this expedition was to obtain genomic quality DNA across anchialine fauna, hologenophore vouchers (Pleijel et al., 2008) were prepared to ensure molecular sequences could be tracked back to individual specimens. This semidestructive approach allows for identification and additional morphological analyses. Morphological vouchers were typically preserved in either 3\% glutaraldehyde or $2-4 \%$ paraformaldehyde, with the occasional preservation in $96 \%$ EtOH when necessitated by downstream protocols. Removal of several taxonomically non-informative structures (pereopods, parapodia, antennae, trunk limbs, etc.) was performed to obtain genomic quality tissue. Dissected parts were placed in alphanumeric tubes preloaded with $150 \mu \mathrm{L}$ of M2 buffer (AutoGen) and stored at $4^{\circ} \mathrm{C}$. Paragenophore vouchers of select individuals were preserved in 96-100\% $\mathrm{EtOH}$ for DNA analyses and in Trizol or RNAlater for RNA analyses. All paragenophore vouchers were stored at $-20^{\circ} \mathrm{C}$ in the field and transferred to $-80^{\circ} \mathrm{C}$ upon returning to the Smithsonian National Museum of Natural History.

Permissions for specimen collection and export were granted through a scientific research permit (SRP No.: 18-12-01-23) issued by the TCI Department of Environment and Coastal Resources (DECR) issued to TMI. All specimens are deposited at the Smithsonian National Museum of Natural History, Washington, D.C., USA (USNM 1524194-1524351).

\section{RESULTS}

Seven anchialine cave systems yielding significant faunal discoveries are known from the Turks and Caicos Islands: four in Providenciales, one in North Caicos, one in Middle Caicos and one in South Caicos. Detailed descriptions for each cave are provided below; exact cave locations have been withheld per the guidelines of our scientific research permit. Specific faunistic information for each cave can be found in Supplemental Table. From this point forward, we 
use the term "stygobite/stygobitic" to refer to those species exclusively known from cave systems, while those species that are only recorded from the Turks and Caicos are referred to as "endemic".

\section{Caicos caves}

\section{Caves in Providenciales Island}

Airport Cave is located at the crest of a hill overlooking Providenciales International Airport car park. It is about $2 \mathrm{~km}$ inland from the coast near the midpoint of the island of Providenciales at the northwestern corner of the Caicos Bank. The cave entrance is a crescent-shaped fissure extending off the side of a much larger, but debris-choked, sinkhole. A narrow ravine-like passage extends down for $20 \mathrm{~m}$ to a tidal anchialine pool lying in total darkness. The maximum water depth is $14 \mathrm{~m}$. A colony of bats roost over the pool and their guano makes up much of the sediment. Based on our most recent visit, this cave should be considered biologically 'dead' in terms of macrofauna, as water pollution and hydrogen sulfide render the water anoxic and unsuitable for supporting animal life. Seven stygobitic species had been previously recorded from this locality, four of which are endemic (see Supplemental Table).

Old Blue Hill Cave is $300 \mathrm{~m}$ to the northeast of Airport Cave on Providenciales. Two pools on opposite sides of a large collapsed sinkhole are separated by massive breakdown boulders. The largest pool, beneath a $7 \mathrm{~m}$ high limestone cliff, opens to sunlight and has several meters of tannic surface water. Below the tannic layer, the water clears and a restricted hole opens into a larger chamber, sloping down and then choked off by a breakdown at $25 \mathrm{~m}$ depth. The second pool is sheltered from direct sunlight in a shallow cave and contains clear water. Seven stygobites are known from this locality, four of which are considered endemic (see Supplemental Table).

Snake Cave is located about $1.5 \mathrm{~km}$ inland and $1.1 \mathrm{~km}$ north of the airport on Providenciales. It consists of a long and narrow, mostly water-filled, fissure forming the margin of a larger collapsed sink. Although parts of the cave pool are dimly illuminated, the back section remains in total darkness. Maximum water depth is $8 \mathrm{~m}$. Due to its remoteness, this cave is rarely visited, with only one stygobite being recorded (see Supplemental Table).

The Hole is a deep sinkhole, located at the crest of Long Bay Hills, a prominent ridgeline on the southwestern side of Providenciales. The cave is a $50 \mathrm{~m}$ diameter and $18 \mathrm{~m}$ deep sinkhole with vertical walls of soft limestone and $200 \mathrm{~m}$ from the nearest open water (Juna Sound on the south coast). Sheer walls surrounding a pool show a close resemblance to cenotes found in northern Yucatán Peninsula, México. This $15 \mathrm{~m}$ long by $10 \mathrm{~m}$ wide pool at the bottom of the depression is open to daylight. It is about 6 to $8 \mathrm{~m}$ deep, but the bottom is completely choked by breakdown and surface debris, such that no human-sized cave passages extends off from it. A total of nine stygobites have been recorded from this cave, having the highest diversity on Providenciales (see Supplemental Table).

\section{Caves in North Caicos Island}

Cottage Pond is a submerged sinkhole, located $4 \mathrm{~km}$ inland from the north coast of North Caicos Island (Fig. 1B). A shallow, rock-rimmed depression encloses a nearly circular pond, $50 \mathrm{~m}$ in diameter. At the surface, murky water limits underwater visibility to about 1-3 m. However, near the center of the pond (20 m depth), a $12 \mathrm{~m}$ long horizontal crack opens into a collapsed chamber $(70 \mathrm{~m}$ in diameter) that reaches water depths of $80 \mathrm{~m}$. A conical debris mound lies directly below the entrance crack ( $40 \mathrm{~m}$ depth) and extends downward to the bottom of the deep chamber. Evidence of prior subaerial exposure in the form of stalactites and flowstone can be found down to 45 $\mathrm{m}$. Layers of hydrogen sulfide accumulate at around $40 \mathrm{~m}$ depth. Currently the best known system in North Caicos, a total of 15 stygobitic (five endemics) are known from Cottage Pond, exhibiting the highest diversity of all known anchialine systems in the Turks and Caicos (see Supplemental Table).

\section{Caves in Middle Caicos Island}

Conch Bar Cave, with over $3 \mathrm{~km}$ of horizontal passageways, is the largest subaerial cave in the Lucayan Archipelago (Fig. 1C) (Smart et al., 2008). The cave consists of a series of large chambers and irregular passageways along the southern margin of an eolianite ridge. A series of phreatic formed, elliptical shaped passages with domed ceilings run towards the interior of the ridge. Passage ceiling elevations extending up to $22 \mathrm{~m}$ above sea level may be related to former mixing zones (haloclines) or water tables. The centrally located main entrance is in a 40 m diameter collapsed depression. From this breakdown entrance chamber, partially flooded passages extend to the east and north. Clear water in these passages is generally about 0.5-1 $\mathrm{m}$ deep, although depths upwards of $15 \mathrm{~m}$ are present in several areas farther into the cave. Scattered throughout the cave, many isolated pools fluctuate tidally indicating the presence of subterranean connections between them. Conch Bar Cave has the second highest diversity in the Turks and Caicos, with 14 recorded stygobites, eight of which are endemic from the islands (see Supplemental Table).

\section{Caves in South Caicos Island}

The Fountain is a tidal spring with brackish water flowing from a narrow crack, being used as the water supply to flood neighboring salt flats. This is the only system known from South Caicos, with only a single recorded stygobite (see Supplemental Table).

\section{Fauna}

Based on the review of all published references for the islands, as well as our new results, 35 anchialine species across three phyla have been recorded in the Turks and Caicos. These include three undetermined species from earlier expeditions (see Supplemental Table), plus three new discoveries during the "Caicos Caves III Expedition". Crustacea comprise most of the records, being represented by 28 species. Among Crustacea, Copepoda is the most numerous group with 12 species (4 Cyclopoida, 8 Calanoida), of which 
five are considered stygobitic (see above). Remipedia is the second largest crustacean group with five species, all stygobitic. Ostracoda and Decapoda have three known species each. While the decapods are all stygobitic, only one ostracod is considered to be stygobitic. Amphipoda is represented by two stygobitic species, while only single species are known for Leptostraca, Stygiomysida and Isopoda.

Other phyla represented in the subterranean environments of the Turks and Caicos Islands are Mollusca, with four species, and Annelida, with three species. All the annelids are considered stygobitic, as opposed to the mollusks, which are exclusively epigean taxa, only capable of surviving at cave entrances.

During the "Caicos Caves III" faunal investigations, we recovered three new cave exclusive species, including two annelids belonging to the genera Mesonerilla and Speleonerilla, and a remipede possibly belonging to a new genus.

A detailed overview of the most relevant anchialine species recorded throughout the Turks and Caicos Islands, including newly collected material, is provided below, including their distribution, phylogenetic affinities and some general remarks. These species are selected based on their phylogenetic or ecological relevance (stygobites) within the cave systems. Accidental species, records lacking formal identification or exclusively epigean species known from cave entrances are only mentioned in Supplemental Table.

\section{Phylum Annelida \\ Suborder Aphroditiformia \\ Family Polynoidae \\ Pelagomacellicephala iliffei Pettibone, 1985}

Fig. 2A

Material examined. Turks and Caicos Islands, North Caicos Island, Cottage Pond, 9 January 2019, 33 m, 1 specimen (juvenile), USNM 1524287; 10 January 2019, 33-44 m, 3 specimens, USNM 1524314, USNM 1524315 , USNM 1524316.

Distribution. Previously only known from Conch Bar Cave, Middle Caicos Island (type locality), but with new collections from Cottage Pond, North Caicos Island.

Remarks. Stygobitic. This is a very rare species that has only been collected twice after its original species description. It is a predator, typically swimming in saline waters of the cave water column. Pelagomacellicephala iliffei originally was known from a single cave locality in Middle Caicos at shallow depths (1-1.5 m), but this latest expedition expands both its distribution and depth range to include Cottage Pond on North Caicos. Individuals putatively identified as $P$. iliffei have been collected throughout the Bahamas, including the islands of Exumas, Eleuthera, Cat and Long, although they differ in body size and number of segments; constituting genetically distinct evolutionary entities (Gonzalez et al., 2017).

Pelagomacellicephala iliffei is closely related to the only other known anchialine cave scale worm, Gesiella jameensis (Hartmann-Schröder, 1974) from
La Corona lava tube in Lanzarote, Canary Islands, Spain (Martinez et al., 2016a). Both species are phylogenetically related to members of the subfamily Macellicephalinae (Gonzalez et al., 2018; Martinez $\&$ Gonzalez, 2018), and therefore, putatively have a deep sea ancestry (Gonzalez et al., 2018; Zhang et al., 2018).

\section{Family Nerillidae Mesonerilla sp.}

Fig. 2B

Material examined. Turks and Caicos Islands, Middle Caicos Island, Conch Bar Cave, 4 January 2019, 0.5-2.0 m cave pools, 2 specimens, USNM 1524205 , USNM 1524206.

Distribution. Only known from Conch Bar Cave, Middle Caicos Island.

Remarks. Stygobitic. Members of this genus typically inhabit interstitial marine sands (Worsaae, 2014). However, in anchialine caves, related species are found in coarse sand sediments or lapilli patches as well as hovering over fine silty sediment (Worsaae et al., 2009). Interstitial or epibenthic species of Mesonerilla are deposit feeders, collecting biofilms or deposited organic matter with the help of their club-shaped palps and buccal ciliation. The records presented herein are the first for the genus from the Turks and Caicos.

Mesonerilla sp. is characterized by the presence of a mid-ventral terminal prolongation of the pygidium, a feature shared by the marine interstitial species $M$. katharinae Worsaee, Mikkelsen \& Martínez, 2019 and M. peteri Worsaae, Mikkelsen \& Martínez, 2019 from the Caribbean; as well as for the anchialine species M. xurxoi Worsaee, Mikkelsen \& Martinez, 2019 from Lanzarote and three undescribed species from Bermuda, México and Cuba (Worsaae et al., 2019a).

\section{Speleonerilla sp.}

Fig. 2C

Material examined. Turks and Caicos Islands, Middle Caicos Island, Conch Bar Cave, 4 January 2019, 0.5-2.0 m cave pools, 2 specimens, USNM 1524243 , USNM 1524244.

Distribution. Only known from Conch Bar Cave, Middle Caicos Island.

Remarks. Stygobitic. All animals were collected from the water column using a plankton net. This genus was originally described from anchialine caves of Bermuda as Longipalpa (Worsaae et al., 2004), but was recently changed to Speleonerilla as the previous name was preoccupied (Worsaae et al., 2019b). Speleonerilla only inhabits anchialine caves, being found anywhere between brackish and fully haline waters in twilight and constant dark zones. Unlike all other Nerillidae, members of Speleonerilla are suspension feeders and live in the water column. This is the first record of the genus in the Turks and Caicos.

Speleonerilla is sister to several interstitial species of the genus Mesonerilla, suggesting that the lineage colonized the water column of anchialine caves 
from marine interstitial environments (Worsaae, 2005). Phylogenetic analyses have found the genus monophyletic, with S. isa Worsaae, Gonzalez, Kerbl, et al., 2018, from Lanzarote, branching near a clade containing the Caribbean species (Worsaae et al., 2019a). Speleonerilla sp. from the Turks and Caicos resembles other Caribbean species morphologically, but unpublished DNA sequences indicate that it may represent a new species (Worsaae et al. unpublished). Microscopical examinations of, e.g., gonoducts and ciliation patterns are currently being conducted in search of diagnostic morphological features.

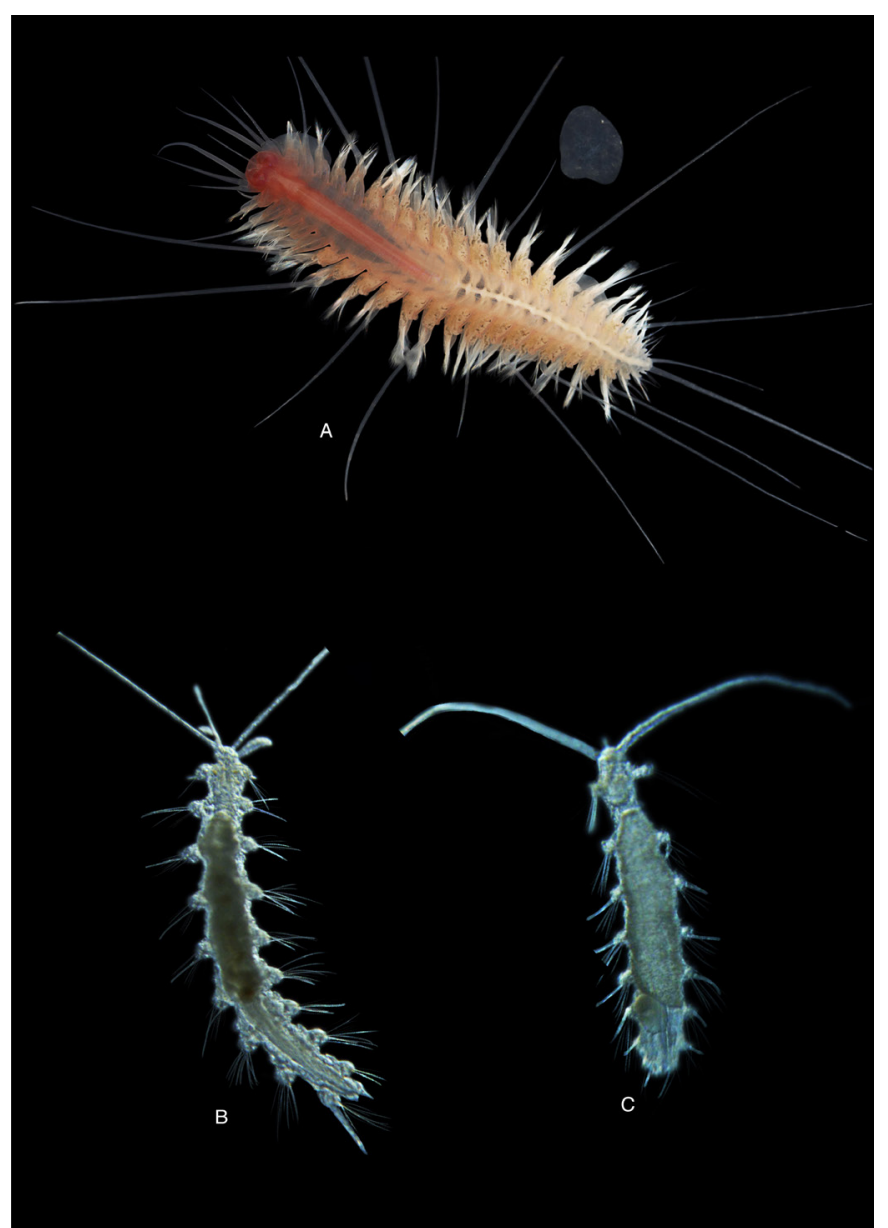

Fig. 2. Anchialine annelids of the Turks and Caicos Islands. A) Pelagomacellicephala iliffei; B) Mesonerilla sp.; C) Speleonerilla sp. Photos by Jørgen Olesen, Brett C. Gonzalez and Katrine Worsaae. Images not to scale.

\section{Phylum Arthropoda \\ Class Copepoda \\ Order Calanoida \\ Family Epacteriscidae \\ Azygonectes plumosus Fosshagen \& Iliffe, 2007 \\ see Fosshagen \& Iliffe (2007)}

Distribution. The type locality is Cottage Pond, North Caicos Island, Turks and Caicos Islands, but is also known from Old Blue Hill Cave, Providenciales, Turks and Caicos Islands.

Remarks. Stygobitic. Found only in the fully haline water column in constant dark zones. This species has only been collected during its discovery. It can be distinguished from other epacteriscids in the Turks and Caicos by the presence of an extremely long setae $\mathrm{V}$ on the left side of the caudal rami.
The only other species described from this genus is A. intermedius Fosshagen \& Iliffe 2007, exclusively known from caves in Andros and Exuma islands, Bahamas. Both species of Azygonectes typically share their habitat with other copepod species, including cyclopoids and ridgewayiid calanoids, which most likely constitute prey items.

Epacteriscidae entirely consists of stygobitic species (Fosshagen \& Iliffe, 2004a), except for Miheptneria abyssalis Andronov, 2007, which has been recorded in the northeast Atlantic at $4622 \mathrm{~m}$ deep. Therefore, a deep-sea affinity can be attributed to the family.

Bofuriella spinosa Fosshagen \& Iliffe, 2007 see Fosshagen \& Iliffe (2007)

Distribution. Only known from the type locality, Conch Bar Cave, Middle Caicos, Turks and Caicos Islands.

Remarks. Stygobitic. Only collected once from the water column in shallow tidal pools in Conch Bar Cave, most of which are open and exposed to low levels of light. These pools frequently accumulate guano from resident bat populations and range from brackish to fully haline, suggesting its tolerance to varying salinities.

Two additional species in the genus are known from the Bahamas: B. parvorata Fosshagen \& Iliffe 2007 from Cat Island and B. vorata Fosshagen, Boxshall \& Iliffe 2001 from the Exuma Cays (Fosshagen et al., 2001; Fosshagen \& Iliffe, 2007). As with other epacteriscids, all species of Bofuriella are raptorial predators.

Caiconectes antiquus Fosshagen \& Iliffe, 2007 see Fosshagen \& Iliffe (2007)

Distribution. The type locality is designated as Cottage Pond, North Caicos Island, Turks and Caicos Islands; however, additional specimens have been collected in Conch Bar Cave on Middle Caicos Island, and Old Blue Hill Cave on Providenciales, Turks and Caicos Islands.

Remarks. Stygobitic. Caiconectes is a monotypic genus endemic from Caicos Islands (Fosshagen \& Iliffe, 2007), found across a wide range of depths and only from the water column. It may be found in entrance pools, twilight or in constant darkness zones. This monotypic species is rarely observed, but has been collected in several localities throughout the Turks and Caicos. Hydrological conditions at the time of collection show high tolerances to variabilities in salinity, temperature and oxygen. Caiconectes has the appearance of a typical hyperbenthic calanoid with raptorial feeding.

\section{Erebonectoides macrochaetus (Fosshagen \&} Iliffe, 1994)

see Fosshagen \& Iliffe (1994); Fosshagen et al. (2001)

Distribution. Only known from two caves. The type locality is The Hole, Providenciales, Turks and Caicos Islands, with additional records from Conch Bar Cave, Middle Caicos, Turks and Caicos Islands. 
Remarks. Stygobitic. This rare monotypic genus is endemic from Caicos Islands, where it is only known from shallow areas of two anchialine caves with intermittent light levels. It is morphologically similar to Erebonectes, represented by the Bermudian endemic species E. nesioticus Fosshagen 1985 (Fosshagen \& Iliffe, 1985). As other epacteriscids, E. macrochaetus is a raptorial predator on small swimming cave organisms.

\section{Family Fosshageniidae}

Fosshagenia ferrari Suárez-Morales \& Iliffe, 1996 see Suárez-Morales \& Iliffe (1996)

Distribution. Only known from the type locality, Conch Bar Cave, Middle Caicos Island, Turks and Caicos Islands.

Remarks. Stygobitic. This rare species is exclusively known from a single collection in the shallow, open pools of Conch Bar Cave (0.5-1 m depth), which are subject to periods of illumination and variability in salinities.

The genus Fosshagenia is known from one additional species, F. suarezi Fosshagen \& Iliffe 2004a, endemic to Grand Bahama (Bahamas) (Fosshagen \& Iliffe, 2004a). The family Fosshageniidae also includes deep-sea species of the genus Temoropia (Boxshall \& Halsey, 2004).

\section{Class Malacostraca \\ Order Amphipoda \\ Family Hadziidae \\ Bahadzia stocki Holsinger, 1985}

Fig. 3A

Material Examined. Turks and Caicos Islands, Providenciales, The Hole, 8 January 2019, 4 - 6 m, 9 specimens, USNM 1524279-1524285.

Distribution. This amphipod inhabits several caves on Providenciales, including Airport Cave (type locality), The Hole and Snake Cave.

Remarks. Stygobitic. This species is known from brackish waters in anchialine cave pools and flooded passages, tolerating extremely low oxygen concentrations. Bahadzia stocki, while only known from three localities, is quite common, and in Airport Cave, is associated with several other crustaceans including remipedes.

The genus Bahadzia includes ten additional species from the Caribbean. Bahamas: B. obliqua Stock, 1986 (Cat Islands); B. setimana Stock, 1986 (South Andros); and B. williamsi Holsinger, 1985 (Grand Bahama and Abaco). Cuba: B. yagerae Ortiz \& Pérez, 1995 and B. patilarga Sawicki, Holsinger, Ortiz \& Pérez 2003 (Matanzas, Cuba). Hispaniola: B. latipalpus Stock, 1986 (Haiti) and B. jaraguensis Jaume \& Wagner 1998 (Dominican Republic). México: B. setodactylus Holsinger, 1992 (Cozumel) and B. bozanici Holsinger 1992 (Cozumel and Yucatán Peninsula). Cayman Islands: B. caymanensis Sawicki \& Holsinger, 2004 (Grand Cayman). The monophyly of the genus is supported by morphological phylogenies, but a molecular phylogeny of the group is still lacking.

\section{Family Pardaliscidae}

Spelaeonicippe provo Stock \& Vermeulen, 1982

Fig. 3B

Material examined. Turks and Caicos Islands, Middle Caicos Island, Conch Bar Cave, 4 \& 7 January 2019, 0.5 - $2.0 \mathrm{~m}$ cave pools, 25 specimens, USNM 1524199, USNM 1524203, USNM 1524215-1524216, USNM 1524246-1524256, USNM 1524260-1524263.

Distribution. This species is widely distributed in the Lucayan Archipelago. From the Turks and Caicos Islands, it occurs in caves on Providenciales, including Airport Cave (type locality, cited as "nameless water hole NW of the airfield" in the original reference), The Hole, Snake Cave and Old Blue Hill Cave, and on Middle Caicos Island from Conch Bar Cave. Additional localities include several Bahamian Islands, including Abaco (Dan's Cave) and the Exuma Cays - Great Guana Cay (Oven Rock Cave) (Stock \& Vermeulen, 1982; van der Ham, 2002).

Remarks. Stygobitic. Specimens were collected in shallow to intermediate depths $(\sim 1-10 \mathrm{~m})$ in cave pools where they were found in dimly illuminated to completely dark waters. No obvious morphological differences have been observed between the different cave populations of $S$. provo across the Lucayan Archipelago, but molecular analyses may reveal the presence of cryptic species or evolutionary units as it has been showed in other stygobites with similar distribution patterns (Gonzalez et al., 2017).

The genus Spelaeonicippe includes one additional species, S. buchi (Andres 1972), endemic to a volcanic cave on Lanzarote, Canary Islands, Spain (Andres, 1975). Spelaeonicippe provo and S. buchi, along with Antronicippe serrata Stock \& Iliffe 1990, which is endemic from Grieta de la Caleta de la Torta on Santa Cruz Island, Galapagos (Stock \& Iliffe, 1990), belong to the family Pardaliscidae, otherwise entirely consisting of deep-sea species. This suggest a deep sea affinity for species of Spelaeonicippe, yet the relationships between deep sea and cave species in these groups have not yet been investigated (Iliffe et al., 1984; Martinez et al., 2016a).

\section{Order Isopoda \\ Family Cirolanidae}

Bahalana caicosana Botosaneanu \& Iliffe, 2003

Fig. 3C

Material examined. Turks and Caicos Islands, Middle Caicos Island, Conch Bar Cave, 4 January 2019, 0.5-2.0 $\mathrm{m}$ cave pools, 1 specimen, USNM 1524212.

Distribution. The type locality is Cottage Pond, North Caicos Island with additional records from Conch Bar Cave, Middle Caicos Island, Turks and Caicos Islands.

Remarks. Stygobitic. The type material of this isopod was collected from 25-46 $\mathrm{m}$ depths in Cottage Pond, as opposed to the shallow depths in Conch Bar Cave in which they were found during the Caicos Caves III expedition. The genus Bahalana includes five additional species from the Bahamas and Cuba. Bahamian species include B. abacoana Botosaneanu 
\& Iliffe, 2006 (Abaco), B. cardiopus Notenboom, 1981 (Acklins and Mayaguana), B. exumina Botosaneanu \& Iliffe, 2002 (Exumas) and B. geracei Carpenter 1981 (Andros, Abaco, Grand Bahama and San Salvador); while one Cuban species is known, B. bowmani Ortiz, Lalana \& Pérez 1997 (Ciénaga de Zapata, Matanzas).

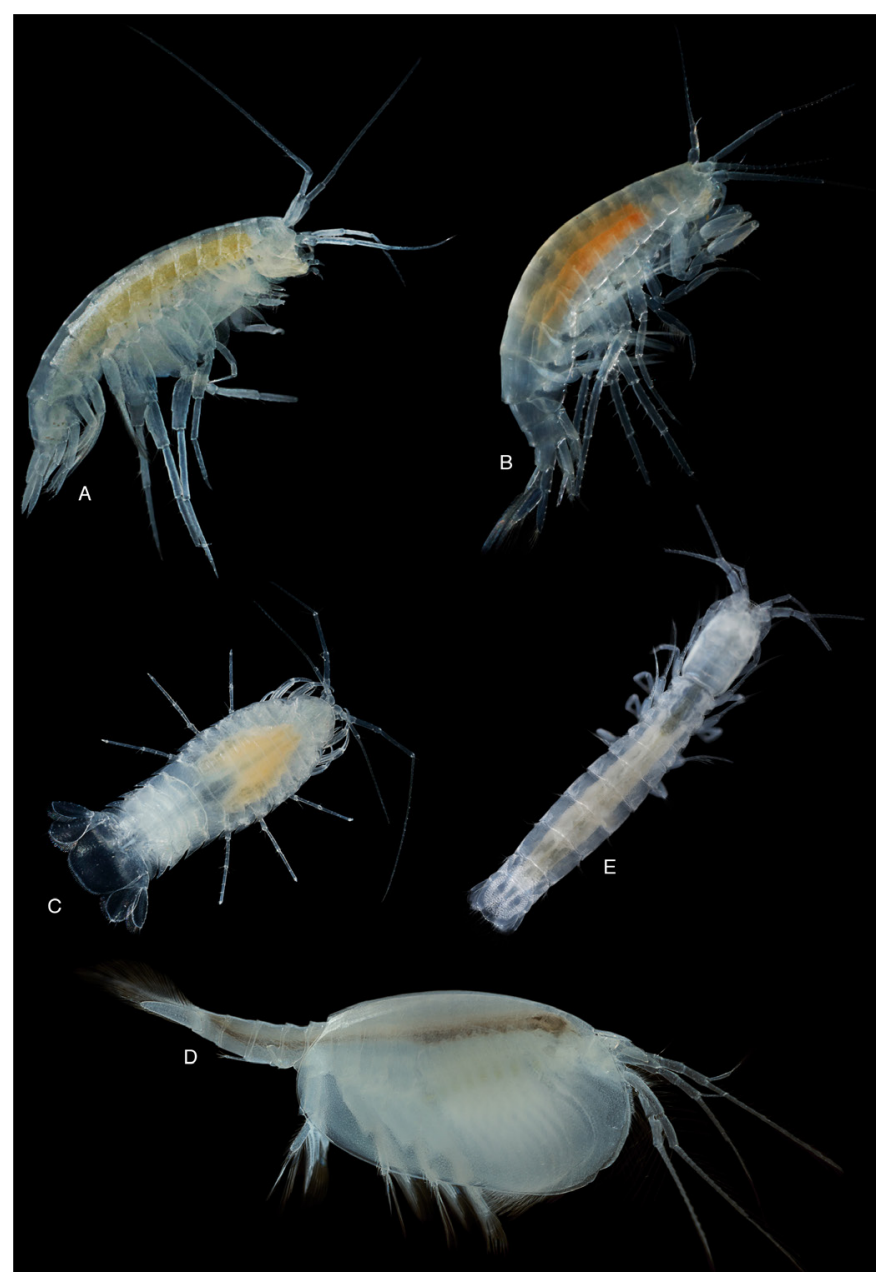

Fig. 3. Assorted anchialine crustaceans of the Turks and Caicos Islands. A) Bahadzia stocki; B) Spelaeonicippe provo; C) Bahalana caicosana; D) Speonebalia cf. cannoni; E) Stygiomysis clarkei. Photos by Jørgen Olesen, Sarit B. Truskey and Brett C. Gonzalez. Images not to scale.

\section{Order Decapoda}

Family Agostocaridiidae

Agostocaris williamsi Hart \& Manning, 1986

Fig. 4A

Material examined. Turks and Caicos Islands, North Caicos Island, Cottage Pond, 9 January 2019, 12-20 m, 1 specimen, USNM 1524288.

Distribution. Big Fountain Blue Hole, Cat Island, Bahamas is the type locality with additional Bahamian locations, including Old Freetown Cave, Grand Bahama Island. From the Turks and Caicos Islands, individuals have been collected in Airport Cave, Providenciales, as well as Cottage Pond, North Caicos Island.

Remarks. Stygobitic. Our specimens were found swimming in the water column or near the bottom, where the species was comparatively abundant. Agostocaris bonzanici has been observed feeding on ground meat in aquaria, suggesting that species of the genus might be scavengers (Mejia-Ortiz, 2010).
The family Agostocaridiidae includes three other cave species: A. acklinsensis Álvarez, Villalobos \& Iliffe, 2004 from Acklins Island (Bahamas); A. bozanici Kensley, 1988 from Yucatán Peninsula (México); and A. zabaletai Mejía-Ortiz, Yañez \& López-Mejía, 2017 from Cozumel Island (México) (Kensley, 1988; Alvarez et al., 2004; Mejía-Ortíz et al., 2017). Species of the family morphologically resemble those in the anchialine family Anchialocarididae, as well as the deep-sea families Alvinocarididae and Mirocarididae (Alvarez et al., 2004; Mejía-Ortíz et al., 2017), suggesting that ancestors of Agostocaris might have colonized anchialine environments from the deep sea.

\section{Family Barbouriidae \\ Barbouria cubensis (von Martens, 1872)}

Fig. 4B

Material examined. Turks and Caicos Islands, Middle Caicos Island, Conch Bar Cave, 4 \& 7 January 2019, 0.5-2.0 m deep cave pools, 3 specimens, USNM 1524202, USNM 1524257, USNM 1524259.

Distribution. Widespread throughout the Bahamas, the Turks and Caicos Islands, Bermuda, Cuba, Cayman Islands, Jamaica and in a few locations along the Caribbean coast of the Yucatán Peninsula, México.

Remarks. Stygobitic. Shrimp were collected from shallow cave pools, where they were found swimming near the guano-rich bottom or amongst the crevices. Pools were in total darkness or dimly illuminated and contained brackish waters. This species is probably a scavenger based on their attraction to baited traps, as well as observations from aquaria (Mejía-Ortíz, 2010; Ditter et al., 2015).

Barbouria cubensis is one of the first described anchialine species, initially reported from Cuba (Barbour, 1945) and afterwards throughout the Caribbean from a wide range of habitats, including open pools and dark cave sections containing brackish to fully haline waters. Despite this broad distribution, animals from geographically distant localities show morphological variation but lack genetic structure based on mitochondrial markers (Ditter et al., 2019), suggesting that they disperse across different island banks. Larval dispersal across distant islands has been also suggested for the Indo-Pacific anchialine shrimp Metabetaus lohena (Russ et al., 2010).

The family Barbouriidae includes $B$. cubensis, together with the Méxican B. yanezi Mejia, Zarza \& López, 2008, four species of the genus Parhippolyte and the deep sea genus Ligur, suggesting a potential deep sea origin for these anchialine shrimp (Hart Jr et al., 1985).

\section{Family Atyidae \\ Typhlatya garciai Chace, 1942}

Fig. 4C

Material examined. Turks and Caicos Islands, Providenciales, Old Blue Hill Cave, 5 January 2019, 01-04 m, 16 specimens, USNM 1524213, USNM 1524219-1524226. Middle Caicos Island, Conch Bar Cave, 4 January 2019, 0.5-2.0 m cave pools, 
10 specimens, USNM 1524197-1524198, USNM

1524201, USNM 1524204, USNM 1524207-1524211.

Distribution. The type locality is Cuba, Holguín Province, Banes; however, T. garciai has been recorded in the Turks and Caicos from the following localities, Conch Bar Cave, Middle Caicos Island, and Old Blue Hill Cave and Snake Cave on Providenciales. From Cuba, localities include Gran Caverna de Santo Tomás (Pinar del Río), cave "Las Cuatrocientas Rozas" in Potrero de Molino and several casimbas (local name for large cracks and crevices amongst the coralline rocks) around Puerto Pesquero (both in Holguín).

Remarks. Stygobitic. These small shrimp are found in waters of salinities ranging from fresh to fully haline. Large populations can literally carpet the bottom at shallow depths of some illuminated cave pools. Interestingly, Botello et al., (2013) found $T$. garciai to be genetically identical to T. kakuki Alvarez, Iliffe \& Villalobos, 2005 from caves on Acklins Island in the Bahamas. Given the slight morphological variations, the underlying genetic diversity appears to be low, and population level genetics are needed to understand relationships between individuals from the known localities.

\section{Order Leptostraca \\ Family Nebaliidae \\ Speonebalia cannoni Bowman, Yager \& Iliffe, 1985 Fig. 3D}

Material examined. Turks and Caicos Islands, North Caicos Island, Cottage Pond, 6 \& 7 January 2019, 22-44 m, 4 specimens, USNM 1524241-1524242, USNM 1524264-1524265.

Distribution. The type locality is Airport Cave with additional records from The Hole, Providenciales, Cottage Pond, North Caicos Island, and from caves in Great Abaco (Bahamas).

Remarks. Stygobitic. Our specimens were observed swimming in the water column of the cave, in total darkness. Specimens were collected from two caves (The Hole and Cottage Pond), but not in Airport Cave due to water pollution. The wide distribution of this species across the Turks and Caicos and the Bahamas needs to be reinvestigated using molecular methods and more detailed morphological studies.

\section{Class Ostracoda \\ Order Halocyprida \\ Deeveya spiralis Kornicker \& Iliffe, 1985}

see Kornicker \& Iliffe (1985)

Material examined. Turks and Caicos Islands, North Caicos Island, Cottage Pond, 7 January 2019, 1 specimen. No museum number assigned.

Distribution. Known from the type locality, The Hole Cave, Providenciales, Turks and Caicos Islands; as well as from Cottage Pond, North Caicos Island.

Remarks Stygobitic. Our specimen was collected using a vial from the water column, where it was seen swimming in total darkness.

Six additional described species make up the genus, all of them from caves in the Bahamas: D. medix
Kornicker in Kornicker, Yager \& Williams, 1990 from Grand Bahama, Exuma and Abaco; D. bransoni Kornicker \& Palmer 1987 and D. hirpex Kornicker in Kornicker, Yager \& Williams, 1990 from Andros; D. exleyi Kornicker \& Iliffe 1998 from the Exumas; and D. jillae Kornicker \& Iliffe 1989 from Eleuthera. Molecular studies are needed to further understand relationships between these species.

\section{Order Stygiomysida Family Stygiomysidae \\ Stygiomysis clarkei Bowman, Iliffe \& Yager, 1984}

Fig. 3E

Material examined. Turks and Caicos Islands, Middle Caicos Island, Conch Bar Cave, 4 \& 7 January 2019, $0.1-2.0 \mathrm{~m}$ deep cave pools, 6 specimens, USNM 1524195-1524196, USNM 1524214, USNM 1524258, USNM 1524266, USNM 1524267.

Distribution. Known from Conch Bar Cave (type locality), Middle Caicos Island, and Snake Cave, Providenciales. This species is also known from Lucayan Caverns, Grand Bahama Island, Bahamas (Bowman et al., 1984; Pesce \& Iliffe, 2002).

Remarks. Stygobitic. These blind, unpigmented crustaceans were found swimming near the guano and mud bottoms of shallow cave pools. Pools were in total darkness or faintly illuminated.

Stygiomysis is a genus with seven described exclusively stygobitic species distributed throughout the Caribbean and Italy. Stygiomysis aemete Wagner, 1992 from Pedernales (Dominican Republic); S. cokei Kallmeyer \& Carpenter, 1996 from Quintana Roo and Yucatán (Yucatán Peninsula, México); S. holthuisi (Gordon 1958) from Anguilla, Saint Martin, Puerto Rico, Grand Bahama, Quintana Roo and Yucatán (México); S. ibarrae Ortiz, Lalana \& Perez 1996 from Matanzas (Cuba); S. major Bowman, 1976 from Jackson Bay (Jamaica); and S. hydruntina Caroli 1937 from Puglia (southern Italy).

\section{Class Remipedia}

\section{Order Nectiopoda}

Family Godzilliidae

Godzillius robustus Schram, Yager \& Emerson, 1986

Fig. 5A

Material examined. Turks and Caicos Islands, North Caicos Island, Cottage Pond, 9 January 2019, at 24$51 \mathrm{~m}$ depths, 3 specimens, USNM 1524345, USNM 1524347, USNM 1524349.

Distribution. Known only from the type locality, Cottage Pond, North Caicos Island (Schram et al. 1986).

Remarks. Stygobitic. Observed swimming in the water column, together with the remipedes Kaloketos pilosus Iliffe \& Yager, 2004 and Lasionectes entrichoma Yager \& Schram, 1986 in deeper waters with total darkness and fully haline salinities.

Godzillius is a remipede genus with two large and robust species distributed in the Caribbean. The other species of the genus is G. fuchsi Gonzalez, Singpiel \& Schlagner, 2013, described from Dan's Cave and Ralph's Sink on Abaco Island, Bahamas, where it co- 


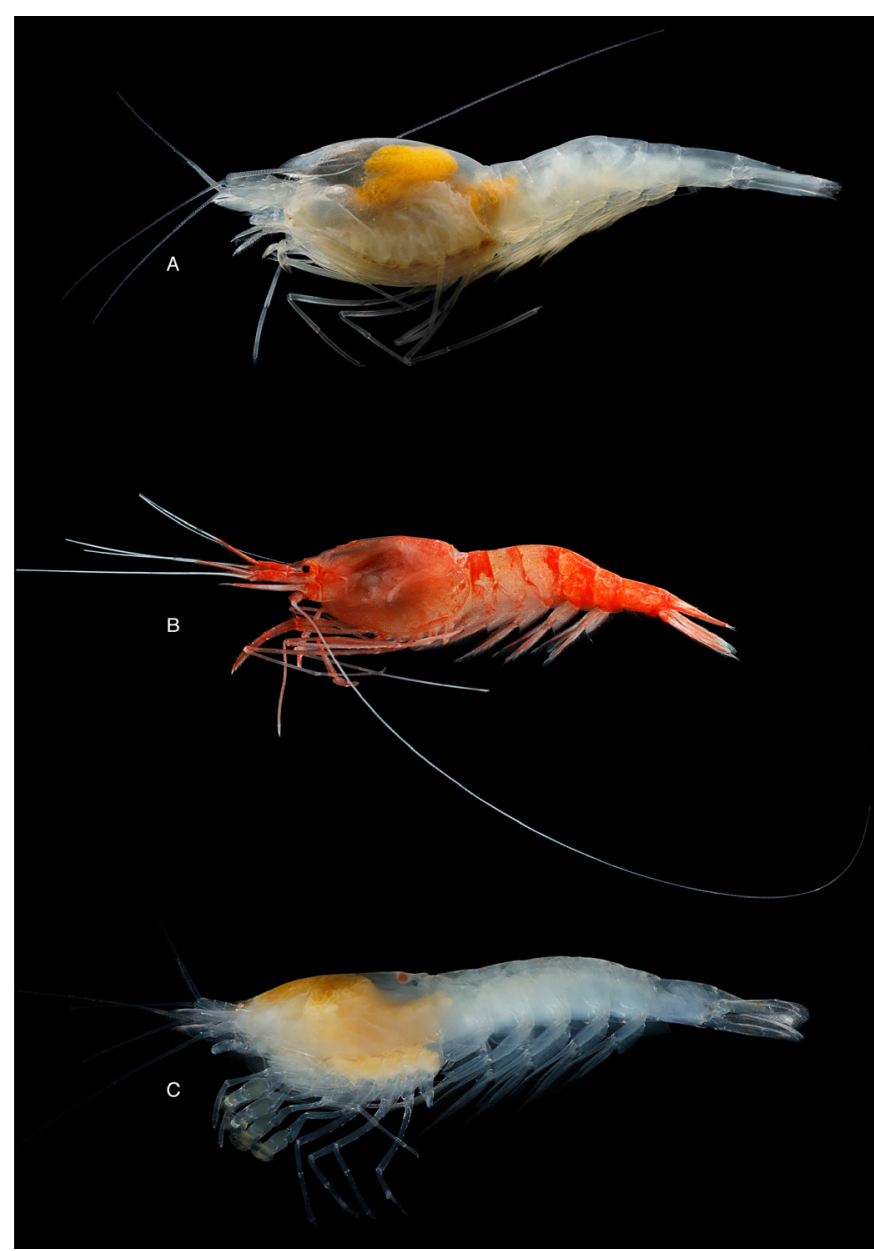

Fig. 4. Anchialine decapods of the Turks and Caicos Islands. A) Agostocaris williamsi; B) Barbouria cubensis; C) Typlatya garciai. Photos by Sarit B. Truskey and Brett C. Gonzalez. Images not to scale.

occurs with at least five additional remipede species (Dan's Cave) (Gonzalez et al., 2013). Currently this is the only remipede genus known from both the Turks and Caicos and the Bahamas.

\section{Family Cryptocorynetidae}

Kaloketos pilosus Koenemann, Iliffe \& Yager, 2004

Fig. 5B

Material examined. Turks and Caicos Islands, North Caicos Island, Cottage Pond, $7 \& 9$ January 2019, at 24-51 m depths, 2 specimens, USNM 1524329, USNM 1524342 .

Distribution. Known only from the type locality, Cottage Pond, North Caicos Island (Koenemann et al., 2004).

Remarks. Stygobitic. Observed swimming in the water column, together with the remipedes $G$. robustus and $L$. entrichoma in deeper waters with total darkness and fully haline salinities.

This monotypic genus is so far endemic of Cottage Pond.

\section{Family Speleonectidae}

\section{Lasionectes entrichoma Yager \& Schram, 1986}

Fig. 5C

Material examined. Turks and Caicos Islands, Providenciales, Old Blue Hill Cave, 5 January 2019, at $22 \mathrm{~m}$ depth, 4 specimens, USNM 1524318-1524321.
North Caicos Island, Cottage Pond, $7 \& 9$ January 2019, at 24-51 $\mathrm{m}$ depths, 21 specimens, USNM 1524323-1524328, USNM 1524330-1524333, USNM 1524335-1524341, USNM 1524343, USNM 1524346, USNM 1524348, USNM 1524350.

Distribution. Known from three locations in the Turks and Caicos Islands, Old Blue Hill Cave (type locality) and Airport Cave on Providenciales, and Cottage Pond, North Caicos Island.

Remarks. Stygobitic. Observed swimming in the water column, together with the remipedes $G$. robustus and $K$. pilosus in deeper cave waters with total darkness and fully haline salinities. Lasionectes entrichoma is by far the most abundant remipede species collected on this current expedition, particularly in Cottage Pond. This species was absent from Airport Cave, from where it has previously been reported, likely due to water pollution.

\section{Family Micropacteridae}

Micropacter yagerae Koenemann, Iliffe \& van der Ham, 2007

Fig. 5D

Material examined. Turks and Caicos Islands, Providenciales, Old Blue Hill, 5 January 2019, at $22 \mathrm{~m}$ depth, 2 specimens, USNM 1524317, USNM 1524322 .

Distribution. Known only from its type locality, Airport Cave, and Old Blue Hill, Providenciales.

Remarks. Stygobitic. Observed swimming in the water column with the remipede $L$. entrichoma. Micropacter yagerae was not collected at its type locality (Airport Cave) during this expedition, which we found degraded and completely depleted of life due to water pollution.

The generic name Micropacter means 'tiny hunter' and refers to the small size of the individuals, superficially resembling juveniles of the family Speleonectidae.

\section{Family c.f. Morlockiidae Morlockia sp. nov.}

Fig. 5E

Material examined. Turks and Caicos Islands, Middle Caicos, Conch Bar Cave, 5 \& 7 January 2019, at $<0.5 \mathrm{~m}$ depth, 3 specimens, USNM 1524194, USNM 1524334, USNM 1524344

Distribution. Known only from the type locality, Conch Bar Cave, Middle Caicos Island.

Remarks. Stygobitic. Our specimens are unusual for remipedes in that they were collected from brackish (21 ppt) surface waters of small, shallow pools, rather than higher salinity water in the deep interior of underwater caves. Only Speleonectes epilimnius Yager \& Carpenter, 1999 has been found in similar conditions, described from a brackish pool (24-25 ppt) at the back of Major's Cave (San Salvador, Bahamas) (Carpenter, 1999). Our specimens co-occurred with S. clarkei.

These specimens are under study, but preliminary attempts to identify the species based on both 
morphology and molecular data limited to one marker (16S rRNA) have been so far inconclusive.

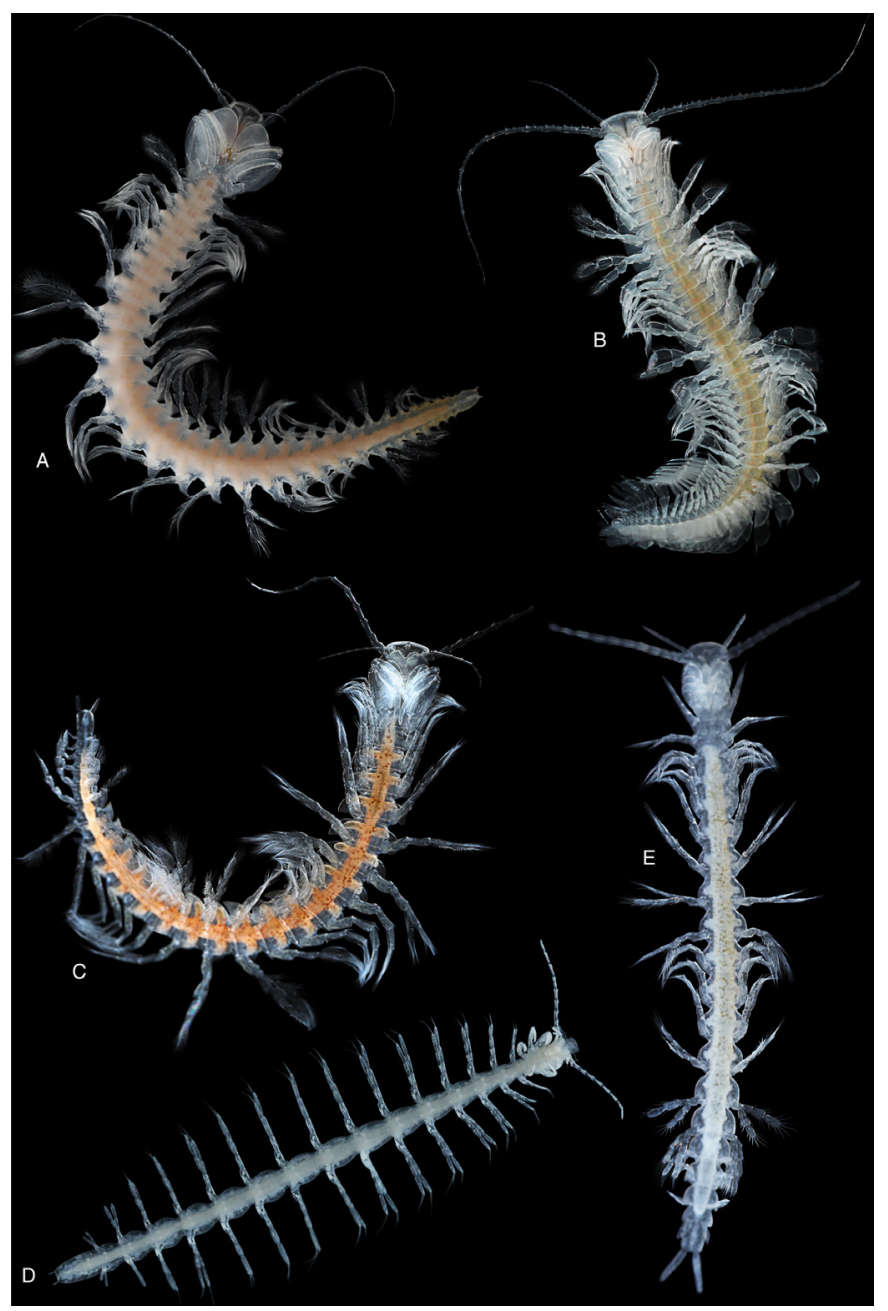

Fig. 5. Remipedes of the Turks and Caicos Islands. A) Godzillius robustus; B) Kaloketos pilosus; C) Lasionectes entrichoma; D) Micropacter yagerae; E) Morlockia sp. nov. All photos by Jørgen Olesen. Images not to scale.

\section{DISCUSSION}

Since the first scientific expedition to the Turks and Caicos Islands in 1975, a total of 32 species of animals have been recorded from aquatic subterranean environments. The Caicos Caves III expedition recorded three additional species, including two new annelids and a new remipede, bringing the total number of known anchialine fauna in the Turks and Caicos to 35,22 of which are known stygobites. Four of these records lack any formal identification or detailed description, but we have included them as they are historical records that were listed during description of accompanying fauna (Stock \& Vermeulen, 1982; Koenemann et al., 2004), providing important information regarding the diversity that these systems sustain (see Supplemental Table). These records include one mollusk (Cochliopidae) and three copepod crustaceans (Oithonidae, Pseudodiaptomidae, Ridgewayiidae; Supplemental Table). Some of this unknown diversity had been collected from hand-dug wells breaching the groundwater, which are known to additionally host epigean freshwater dispersalist species (see for example Pesce 1985; Bowman 1986). Recent expeditions, including Caicos Caves III, omitted sampling of this type due to sediment infilling of the wells and their limited access to subsurface haline waters, possibly missing numerous representatives (mainly crustaceans) throughout the Turks and Caicos.

As in prior expeditions, we too recovered potentially new species (two annelids and one remipede), as well as new records for the Turks and Caicos. Our report of Mesonerilla and Speleonerilla (both belonging to family Nerillidae, Annelida) is of particular interest because the only annelid previously known from the Turks and Caicos caves was the polynoid scale worm, Pelagomacellicephala. The presence of Mesonerilla in Conch Bar Cave is not surprising; it is a widespread genus of annelid, found in both cave and non-cave interstitial habitats throughout the world and typically lacks obvious cave-specific adaptations (Worsaae et al., 2009, 2019a). Speleonerilla, in contrast, is a cave-adapted genus, currently known from disjunct localities, including Yucatán Peninsula (México), the Bahamas, Bermuda, Cuba and Lanzarote (Canary Islands), secondarily adapted to feed on suspended organic matter in the water column of anchialine caves (Worsaae et al., 2019b). Currently this is the southernmost record for Speleonerilla. Their widespread occurrence in the Caribbean and Atlantic suggests that increased sampling efforts would likely result in the discovery of additional species from anchialine habitats elsewhere in the region.

Our most unexpected discovery of this expedition was the putative new remipede species from Conch Bar Cave, Middle Caicos. Surprisingly, specimens were found in small pools less than $1 \mathrm{~m}$ deep. These collections all happened during an incoming tide, reiterating the importance and presence of a spelean corridor, permitting unhindered movements throughout the carbonate platform. Occasionally other species have also been found in shallow anchialine cave pool habitats (i.e., Morlockia ondinae GarciaValdecasas, 1984 in Lanzarote, Martínez pers. obs.). This is the first record of a remipede from Conch Bar Cave and from the island of Middle Caicos, making it the fifth remipede species for the Turks and Caicos Islands.

Similar to other Caribbean localities (i.e., Yucatán Peninsula and the Bahamas), several of the anchialine species found in this expedition are known from multiple Caicos islands (i.e., Providenciales, Middle, North) or have broader distributions across the Caribbean and Atlantic (see Supplemental Table). Diving collections from the Caicos Caves III expedition has extended the known range of $P$. iliffei within the Caicos Bank, originally described from shallow cave pools in Conch Bar Cave, Middle Caicos, to now also inhabit deep cave waters in Cottage Pond, North Caicos Island. While specimens from both localities are not currently available for genetic comparisons, morphologically, these annelids appear identical. It remains unknown what degree of connectivity exists between the Turks and Caicos Islands; however, Gonzalez et al., (2017) showed evidence of an active spelean corridor on the island of Eleuthera, Bahamas, whereby genetically identical species of $P$. iliffei were found from caves in excess of $100 \mathrm{~km}$ apart. 
The idea of a spelean corridor is not new - originally and somewhat flippantly suggested by Chace \& Hobbs (1969), the idea was largely overlooked or dismissed until recently. Nevertheless, continued faunal surveys incorporating molecular methods (Alvarez et al., 2015) have shown this concept to be a viable means towards the broad, regional distributions seen in anchialine fauna (Santos, 2006; Hunter et al., 2008; Botello \& Álvarez, 2010). In the Turks and Caicos, several crustaceans are also likely utilizing such means for distribution, including Agostocaris williamsi, Barbouria cubensis, Lasionectes entrichoma, Stygiomysis clarkei, Spelaeonicippe provo and Typhlatya garciai, all of which are found in multiple island and cave localities on the Caicos Bank. Similar to $P$. iliffei, some of these crustaceans are also known from locations outside the Turks and Caicos Islands, including the Bahamas, Yucatán Peninsula, Cuba, Jamaica and the Lesser Antilles, depending on the species. While phylogeographic analyses are lacking for many of these species, it is likely that they comprise different evolutionary histories related to the presence of certain functional traits (i.e., larvae, body size, salinity tolerance) and the age of each lineage.

Considering the new records presented herein, it is evident that substantial undocumented diversity is still to be found in the anchialine realm. New species are constantly described even in relatively wellinvestigated and easily accessible anchialine systems, including for example those in Yucatán Peninsula and Lanzarote, where six (Rubio et al., 2015; SuárezMorales et al., 2017b, 2017a; Angyal et al., 2018; Grego et al., 2019; Sánchez \& Martínez, 2019) and five new species (Martínez et al., 2016b; Gobert et al., 2019; Worsaae et al., 2019a, 2019b), respectively, have been described within the last five years. These numbers highlight the importance of continued exploration, particularly considering that some anchialine species may use different habitats rather than caves, appearing only occasionally in caves (Martinez et al., 2013). While none of the anchialine species in the Turks and Caicos are currently protected, their small populations, relatively low densities and endemism are sufficient reasons to encourage this situation to change. In addition, a better understanding of anchialine communities would allow us to better predict how these presumably isolated but delicate ecosystems will respond to ongoing environmental change and human impacts (Mammola et al., 2019).

\section{Threats to Caicos Caves and its Biodiversity}

Caves are rare and fragile environments that once damaged or destroyed, are lost forever. Low densities of endemic, blind and depigmented organisms, often known from only a single location, are constantly at risk or under threats of extinction (Mammola et al., 2019). Cave waters are particularly susceptible to anthropogenic disturbances as they already exhibit extreme physiochemistries, being characterized as lightless, oxygen and food deprived habitats (Gonzalez et al., 2011). Cave animals living in these environments are often forced to switch for short periods of time to less efficient anaerobic metabolism in order to survive periods of low oxygen stress (Bishop et al., 2004). These stressors vary in form, but generally, subterranean ground waters are highly susceptible to pollution and contamination through inadequate wastewater disposal, leeching from solid waste landfills or unsanitary use of caves and groundwater (Iliffe, 1979; Martínez et al., 2020).

In 2013, Iliffe became aware that an extension of the Providenciales Airport Parking area was planned near Airport Cave. Previous diving explorations and biological collections from Airport Cave on Providenciales in 1982, 1983 and 2003 resulted in the discovery of five new species of cave-adapted crustaceans making it one of the most biologically significant caves in the country. Letters to governmental departments explaining the importance of this cave and its unique fauna were sent, urging steps be taken to protect and preserve this cave site since the property is owned by the Airport Authority. Completion of the parking area occurred as planned, yet with no obvious or immediate disturbances to the area around the cave entrance. However, upon our most recent 2019 trip to Airport Cave, the entrance pool was found to be devoid of life, likely due to exhaustion of oxygen from the water. Earlier reports several years prior to 2019 from colleagues had similarly reported foul and polluted water conditions for Airport Cave. The exact cause of the oxygen depletion is unclear, but several possibilities exist. Guano from the colony of bats nesting in the cave ceiling may have increased into the pool, resulting in an increase in bacterial utilization. Alternatively, hydrological parameters may have changed as buildup of fine, silty sediments throughout the cave caused a further reduction to subterranean groundwater circulation. However, these two issues are historical processes to caves of the Turks and Caicos Islands, and being that only Airport Cave is afflicted, it is highly suggestive of anthropogenic disturbances. Similar single cave 'die offs' have been known elsewhere throughout the Lucayan Archipelago (pers. obs.) and are often traceable back to changes in ground use or water pollution. Perhaps sewage from the adjacent airport complex is further polluting the groundwater, or construction of the airport's parking lot may have blocked off underground flow channels. Until additional studies are carried out, there is no way to know for sure. Additional concerns and problems and were also observed in 2019 at Old Blue Hill Cave, the only other site on Providenciales where remipedes have been found. While this cave is located in a relatively remote part of the island, a group of people have set up a makeshift encampment, and are using the cave pool for bathing and laundering of clothes. What long-term impact this may have on water quality and the cave fauna is unclear.

In any event, cave species tend to be present in low numbers and constrained to a narrow depth range in small parts of the caves. Due to their highly restricted distribution, low population sizes and environmentally threatened habitats, most Caicos cave animals qualify for classification as endangered. As a result, subterranean environments of the Turks and Caicos Islands are valuable and in need of effective legal 
protection, especially as island developments and anthropogenic encroachment continues.

\section{ACKNOWLEDGEMENTS}

Members of the "Caicos Caves III" team would like to recognize all the members of the previous expeditions and contributing taxonomists who paved the way to furthering our understanding of anchialine systems throughout the Caribbean. We also would like to personally thank and recognize Stefan Koenemann for his meticulous and invaluable contributions towards the taxonomy and systematics of Remipedia, a legacy of collections and information still generating new and exciting findings. Support for this project was made possible through generous contributions by the Smithsonian's Global Genome Initiative - Rolling Awards Program (GGI-2019-Rolling-214 to KJO) and the Peter Buck Fellowship Program (to BCG). Special thanks to the Department of Environment and Coastal Resources (DECR) - Ministry of Tourism, Environment, Heritage, Culture \& Gaming for their willingness to grant collection and export permits to our team. We would also like to express our gratitude to Marisol Arciniega-Melendez for heroic travel administration support given the 2019 government shutdown. Thank you, Rhonda Hart, for ensuring a constant supply of scrumptious vittles throughout our long days and nights of sample processing. Generous travel support for MAL was provided by the Danish Natural History Society. Work conducted by LB is supported by the National Science Foundation Graduate Research Fellowship under Grant No. M1703014. AM trip expenses and subsequent work was supported by a Marie Skolodowska-Curie Individual Grant ("ANCAVE - Anchialine caves as models for Evolution; IFEF, number 745530").

Authorship statement: All authors contributed to the collection and preservation of animals used in this study. BCG, TMI, KW and KJO designed this study. BCG, AM, JO, SBT, LB, MAL, JD, TMI and KW photographed and identified all collected material. On-site logistics, transportation, diving support and permitting were made possible through $\mathrm{PH}, \mathrm{MP}, \mathrm{NM}$ and JW. Funding was provided by KJO and BCG. BCG and AM wrote the manuscript with KJO and KW. All authors edited and approved the final draft.

\section{REFERENCES}

Alvarez, F., Iliffe, T.M., Benitez, S., Brankovits, D., Villalobos, J.L., 2015. New records of anchialine fauna from the Yucatan Peninsula, Mexico. Check List, 11, 1-10. https://doi.org/10.15560/11.1.1505

Alvarez, F., Villalobos, J.L., Iliffe, T.M., 2004. A new species of Agostocaris (Caridea: Agostocarididae) from Acklins Island, Bahamas. Proceedings of the Biological Society of Washington, 117, 368-376.

Andres, H. von., 1975. Nicippe buchi, n. sp., ein Pardaliscide aus einem Lavatunnel auf Lanzarote (Amphipoda, Crustacea). Mitteilungen aus den Hamburgischen Zoologischen Museum und Institut, 72, 91-95.
Angyal, D., Solís, E.C., Magaña, B., Balázs, G., Simoes, N., 2018. Mayaweckelia troglomorpha, a new subterranean amphipod species from Yucatán state, México (Amphipoda, Hadziidae). ZooKeys, 1-25. https://doi.org/10.3897/zookeys.735.21164

Barbour, T., 1945. A naturalist in Cuba. Brown and Company, Boston, Massachusetts.

Biernbaum, C.K., 1996. Biogeography of coastal and anchialine amphipods of Ascension Island, South Atlantic Ocean. Journal of Natural History, 30, 15971615. https://doi.org/10.1080/00222939600770931

Bishop, R.E., Kakuk, B., Torres, J.J., 2004. Life in the hypoxic and anoxic zones: metabolism and proximate composition of Caribbean troglobitic crustaceans with observations on the water chemistry of two anchialine caves. Journal of Crustacean Biology, 24, 379-392.

https://doi.org/10.1651/C-2459

Botello, A., Álvarez, F., 2010. Genetic variation in the stygobitic shrimp Creaseria morleyi (Decapoda: Palaemonidae), evidence of bottlenecks and reinvasions in the Yucatan Peninsula. Biological Journal of the Linnean Society, 99, 315-325.

https://doi.org/10.1111/j.1095-8312.2009.01355.x

Botello, A., Iliffe, T.M., Alvarez, F., Juan, C., Pons, J., Jaume, D., 2013. Historical biogeography and phylogeny of Typhlatya cave shrimps (Decapoda: Atyidae) based on mitochondrial and nuclear data. Journal of Biogeography, 40, 594-607.

https://doi.org/10.1111/jbi.12020

Botosaneanu L., Iliffe, T.M., 2003. A new species of stygobitic cirolanid genus Bahalana from Caicos Islands in the Caribbean (Isopoda: Cirolanidae). Travaux du Muséum Natural d'Histoire Naturelle Grigore Antipa, 45, 83-93.

Botosaneanu, L., 2000. Cayman Islands; Turk and Caicos Islands; some leeward and windward islands; Barbados; Trinidad and Tobago; the Venezuelan Islands. Encyclopaedia biospeologica, III, 1387-1395.

Bowman, T.E., 1986. Freshwater calanoid copepods of the West Indies. Syllogeus, 58, 237-246.

Bowman, T.E., Iliffe, T.M., Yager, J., 1984. New records of the troglobitic mysid genus Stygiomysis: S. clarkei, new species, from the Caicos Islands, and S. holthuisi (Gordon) from Grand Bahama Island (Crustacea: Mysidacea). Proceedings of the Biological Society of Washington, 97, 637-644.

Bowman, T.E., Yager, J., Iliffe, T.M., 1985. Speonebalia cannoni, n. gen., n. sp., from the Caicos Islands, the first hypogean leptostracan (Nebaliacea: Nebaliidae). Proceedings of The Biological Society of Washington, 98, 439-446.

Boxshall, G.A., Halsey, S.H., 2004. An introduction to copepod diversity. The Ray Society, London, 966 p.

Broodbakker, N.W., 1984. The distribution and zoogeography of freshwater Ostracoda (Crustacea) in the West Indies, with emphasis on species inhabiting wells. Bijdragen tot de Dierkunde, 54, 25-50. https://doi.org/10.1163/26660644-05401003

Broodbakker, N.W., 1983. Amsterdam Expeditions to the West Indian Islands, Report 24. The genus Heterocypris (Crustacea, Ostracoda) in the West Indies. II. Carapace length, ecology and zoogeography. Bijdragen tot de Dierkunde, 53, 115-134. https://doi.org/10.1163/26660644-05301010

Buden, D.W., Felder, D.L., 1977. Cave shrimps in the Caicos Islands. Proceedings of the Biological Society of Washington, 90, 108-115.

Carpenter, J., 1999. Behavior and ecology of Speleonectes epilimnius (Remipedia, Speleonectidae) from surface 
water of an anchialine cave on San Salvador Island, Bahamas. Crustaceana, 72, 979-991.

https://doi.org/10.1163/156854099503889

Chace, F.A., Hobbs, H.H., 1969. The freshwater and terrestrial decapod crustaceans of the West Indies with special reference to Dominica. U.S. National Museum Bulletin, 292, 1-258.

https://doi.org/10.5479/si.03629236.292.1

Orghidan, T., Nunez-Jimenez, A., Botosaneanu, L., Decou, V., Negrea, Ş., Bayes, N.V., 1973. Résultats des expéditions biospéologiques Cubano-Roumaines à Cuba. In: Editura Academiei RSR, Bucuresti, 424 p.

Dietz, R.S., Holden, J.C., Sproll, W.P., 1970. Geotectonic evolution and subsidence of Bahama platform. Geological Society of America Bulletin, 81, 1915-1928. https://doi.org/10.1130/0016-7606(1970)81 [1915:GEASOB]2.0.CO;2

Ditter, R.E., Erdman, R.B., Goebel, A.M., BrackenGrissom, H.D., 2019. Widespread phenotypic hypervariation in the enigmatic anchialine shrimp Barbouria cubensis (Decapoda: Barbouriidae). Zootaxa, 4648, 1-26.

https://doi.org/10.11646/zootaxa.4648.1.1

Ditter, R.E., Goebel, A.M., Erdman, R.B., 2015. First Record of the anchialine shrimp Parhippolyte sterreri (Decapoda, Barbouriidae) from San Salvador Island, Bahamas, with observations on Barbouria cubensis. Marine Biodiversity Records, 8, 1-4.

https://doi.org/10.1017/S1755267215000196

Dravis, J.J., Wanless, H.R., 2008. Caicos platform models of Quaternary carbonate deposition controlled by stronger easterly Trade Winds-application to petroleum exploration. SEPN Core Workshop, 22, 21 27. https://doi.org/10.2110/pec.08.22.0021

Fosshagen, A., Boxshall, G.A., Iliffe, T.M., 2001. The Epacteriscidae, a cave-living family of calanoid copepods. Sarsia, 86, 245-318.

https://doi.org/10.1080/00364827.2001.10425520

Fosshagen, A., Iliffe, T.M., 2007. New species of epacteriscids (Copepoda, Calanoida) from anchialine caves in the Caicos Islands and the Bahamas. Marine Biology Research, 3, 73-92.

https://doi.org/10.1080/17451000701274571

Fosshagen, A., Iliffe, T.M., 2004a. New epacteriscids (Copepoda, Calanoida) from anchialine caves in the Bahamas. Sarsia, 89, 117-136.

https://doi.org/10.1080/00364820410004981

Fosshagen, A., Iliffe, T.M., 2004b. A new species of caveliving calanoid copepod from Grand Bahama. Sarsia, 89, 346-354.

https://doi.org/10.1080/00364820410002613

Fosshagen, A., Iliffe, T.M., 1994. A new species of Erebonectes (Copepoda, Calanoida) from marine caves on Caicos Islands, West Indies. Hydrobiologia, 292293, 17-22. https://doi.org/10.1007/BF00229918

Fosshagen, A., Iliffe, T.M., 1985. Two new genera of Calanoida and a new order of Copepoda, Platycopioida, from marine caves in Bermuda. Sarsia, 70, 345-358. https://doi.org/10.1080/00364827.1985.10419688

Gobert, S., Reygel, P., Artois, T., 2019. Schizorhynchia (Platyhelminthes Rhabdocoela) of Lanzarote (Canary Islands), with the description of eight new species. Marine Biodiversity, 49, 2089-2107. https://doi.org/10.1007/s12526-017-0736-x

Gonzalez, B.C., Iliffe, T.M., Macalady, J.L., Schaperdoth, I., Kakuk, B., 2011. Microbial hotspots in anchialine blue holes: initial discoveries from the Bahamas. Hydrobiologia, 677, 149-156.

https://doi.org/10.1007/s10750-011-0932-9
Gonzalez, B.C., Martínez, A., Borda, E., Iliffe, T.M., Eibye-Jacobsen, D., Worsaae, K., 2018. Phylogeny and systematics of Aphroditiformia. Cladistics, 34, 225259. https://doi.org/10.1111/cla.12202

Gonzalez, B.C., Martínez, A., Borda, E., Iliffe, T.M., Fontaneto, D., Worsaae, K., 2017. Genetic spatial structure of an anchialine cave annelid indicates connectivity within - but not between - islands of the Great Bahama Bank. Molecular Phylogenetics and Evolution, 109, 259-270.

https://doi.org/10.1016/j.ympev.2017.01.003

Gonzalez, B.C., Singpiel, A., Schlagner, P., 2013. Godzillius fuchsi, a new species of Remipedia (Godzilliidae) from Abaco Island, Bahamas. Journal of Crustacean Biology, 33, 275-285. https://doi.org/10.1163/1937240X-00002132

Grego, J., Angyal, D., Beltrán, L.A.L., 2019. First record of subterranean freshwater gastropods (Mollusca, Gastropoda, Cochliopidae) from the cenotes of Yucatán state. Subterranean Biology, 29, 79-88. https://doi.org/10.3897/subtbiol.29.32779

Gregor, V.A., 1981. Karst and caves in the Turks and Caicos Islands. Proceedings of the Eighth International Congress of Speleology. Bowling Green, KY, p. 805-807.

Guidry, S.A., Grasmueck, M., Carpenter, D.G., Gombos Jr, A.M., Bachtel, S.L., Viggiano, D.A., 2007. Karst and early fracture networks in carbonates, Turks and Caicos Islands, British West Indies. Journal of Sedimentary Research, 77, 508-524. https://doi.org/10.2110/jsr.2007.052

Hart, Jr., C.W., Manning, R.B., Iliffe, T.M., 1985. The fauna of Atlantic marine caves: evidence of dispersal by sea floor spreading while maintaining ties to deep waters. Proceedings of the Biological Society of Washington, 98, 288-292.

Hart, C., Manning, R., 1986. Two new shrimps (Procarididae and Agostocarididae, new family) from marine caves of the western North Atlantic. Journal of Crustacean Biology, 6, 408-416 https://doi.org/10.1163/193724086X00262

Holsinger, J.R., Yager, J., 1985. A new genus and two new species of subterranean amphipod crustaceans (Hadziidae) from the Bahamas and Turks and Caicos Islands. Bijdragen tot de Dierkunde, 55, 283-294. https://doi.org/10.1163/26660644-05502008

Holthuis, L.B., 1973. Caridean shrimps found in landlocked saltwater pools at four Indo-West Pacific localities (Sinai Peninsula, Funafuti Atoll, Maui and Hawaii Islands): with the description of one new genus and four new species. Zoologische Verhandelingen, $128,3-55$.

Hunter, R.L., Webb, M.S., Iliffe, T.M., Bremer, J.R.A., 2008. Phylogeny and historical biogeography of the cave-adapted shrimp genus Typhlatya (Atyidae) in the Caribbean Sea and western Atlantic. Journal of Biogeography, 35, 65-75. https://doi.org/10.1111/j.1365-2699.2007.01767.x

Iliffe, T.M., 2005. Biodiversity in anchialine caves. In: Encyclopedia of caves. Elsevier Academic Press, London, p. 24-30.

Iliffe, T. M., 2000. Anchialine cave ecology. In: Wilkens, H., Culver, D.C., Humphreys, W.F. (Eds.), Ecosystems of the world, 30, Subterranean ecosystems. Elsevier, Amsterdam, p. 59-76.

Iliffe, T.M., 1986. The zonation model for the evolution of aquatic faunas in anchialine caves. Stygologia, 2, 2-9.

Iliffe, T.M., 1979. Bermuda's Caves: a non-renewable resource. Environmental Conservation, 6, 181-186. https://doi.org/10.1017/S037689290000299X 
Iliffe, T.M., Alvarez, F., 2018. Research in anchialine caves. In: Cave ecology, ecological studies. Springer, Switzerland, p. 383-397. https://doi.org/10.1007/978-3-319-98852-8 18

Iliffe, T.M., Hart, C.W.J., Manning, R.B., 1983. Biogeography and the caves of Bermuda. Nature, 302, 141-142. https://doi.org/10.1038/302141a0

Iliffe, T.M., Sarbu, S., 1990. Anchialine caves and cave fauna of the South Pacific. NSS News, 48, 88-96.

Iliffe, T.M., Wilkens, H., Parzefall, J., Williams, D., 1984. Marine lava cave fauna: composition, biogeography, and origins. Science, 225, 309-311. https://doi.org/10.1126/science.225.4659.309

Kensley, B., 1988. New species and records of cave shrimps from the Yucatan Peninsula (Decapoda: Agostocarididae and Hippolytidae). Journal of Crustacean Biology, 8, 688-699.

https://doi.org/10.1163/193724088X00521

Koenemann, S., Iliffe, T.M., Yager, J., 2004. Kaloketos pilosus, a new genus and species of Remipedia (Crustacea) from the Turks and Caicos Islands. Zootaxa, 618, 1-12.

https://doi.org/10.11646/zootaxa.618.1.1

Koenemann, S., Iliffe T.M., Van der Ham, J.L., 2007. Micropacteridae, a new family of Remipedia (Crustacea) from the Turks and Caicos Islands. Organisms, Diversity \& Evolution, 7, 52.e1-52.e14. https://doi.org/10.1016/j.ode.2006.07.002

Koenemann, S., Schram, F.R., Iliffe, T.M., Hinderstein, L.M., Bloechl, A., 2007. Behavior of Remipedia in the laboratory, with supporting field observations. Journal of Crustacean Biology, 27, 534-542. https://doi.org/10.1651/S-2809A.1

Kornicker L., Iliffe, T.M., Harrison-Nelson, E., 2008. Ontogeny of Deeveya spiralis Kornicker \& Iliffe, 1985, collected in anchialine caves in the Caicos Islands (Crustacea, Ostracoda, Halocyprida, Deeveyidae). Proceedings of Biological Society of Washington, 121, 311-353. https://doi.org/10.2988/08-06.1

Kornicker, L.S., Iliffe, T.M., 1992. Ostracoda (Halocypridina, Cladocopina) from anchialine caves in Jamaica, West Indies. Smithsonian Contributions to Zoology, 1-22.

https://doi.org/10.5479/si.00810282.530

Kornicker, L., Yager, J., Williams, D., 1990. Ostracoda (Halocyprididae) from anchialine caves in the Bahamas. Smithsonian Contributions to Zoology, 495, 1-51. https://doi.org/10.5479/si.00810282.495

Kornicker, L., Iliffe, T.M., 1989. New Ostracoda (Halocyprida: Thaumatocyprididae and Halocyprididae) from anchialine caves in the Bahamas, Palau and Mexico. Smithsonian Contributions to Zoology, 470, 1-47. https://doi.org/10.5479/si.00810282.470

Kornicker, L., Palmer, R., 1987. Deeveya bransoni, a new species of troglobitic halocyprid ostracode from anchialine caves on South Andros Island, Bahamas (Crustacea: Ostracoda). Proceedings of the Biological Society of Washington, 100, 610-623.

Kornicker, L.S., Iliffe, T.M., 1985. Deeveyinae, a new subfamily of Ostracoda (Halocyprididae) from a marine cave on the Turks and Caicos Islands. Proceedings of the Biological Society of Washington, 98, 476-493.

Kristjánsson, B.K., Svavarsson, J., 2007. Subglacial refugia in Iceland enabled groundwater amphipods to survive glaciations. The American Naturalist, 170, 292-296. https://doi.org/10.1086/518951

Mammola, S., Cardoso, P., Culver, D.C., Deharveng, L., Ferreira, R.L., Fišer, C., Galassi, D.M.P., Griebler, C., Halse, S., Humphreys, W.F., Isaia, M., Malard, F.,
Martinez, A., Moldovan, O.T., Niemiller, M.L., Pavlek, M., Reboleira, A.S.P.S., Souza-Silva, M., Teeling, E.C., Wynne, J.J., Zagmajster, M., 2019. Scientists' warning on the conservation of subterranean ecosystems. BioScience, 69, 641-650.

https://doi.org/10.1093/biosci/biz064

Martínez, A., Di Cesare, A., Mari-Mena, N., GarcíaGómez, G., Garcia-Herrero, A., Corno, G., Fontaneto, D., Eckert, E.M., 2020. Tossed 'good luck' coins as vectors for anthropogenic pollution into aquatic environment. Environmental Pollution, 259, 113800.

https://doi.org/10.1016/j.envpol.2019.113800

Martínez, A., Di Domenico, M., Worsaae, K., 2013. Evolution of cave Axiokebuita and Speleobregma (Scalibregmatidae, Annelida). Zoologica Scripta, 42, 623-636. https://doi.org/10.1111/zsc.12024

Martínez, A., Gonzalez, B.C., 2018. Volcanic anchialine habitats of Lanzarote. In: Moldovan, O.T., Kováč, L., Halse, S. (Eds.), Cave ecology. Springer International Publishing, Cham, p. 399-414.

https://doi.org/10.1007/978-3-319-98852-8 19

Martínez, A., Gonzalez, B.C., Wilkens, H., Núñez, J., Oromí, P., Iliffe, T.M., Worsaae, K., 2016a. Guide to the anchialine ecosystems of Los Jameos del Agua and Túnel de la Atlántida. Medio Ambientem, Cabildo de Lanzarote, Arrecife, Lanzarote, Spain.

Martínez, A., Kvindebjerg, K., Iliffe, T.M., Worsaae, K., 2016b. Evolution of cave suspension feeding in Protodrilidae (Annelida). Zoologica Scripta, 46, 214-226. https://doi.org/10.1111/zsc.12198

Martínez García, A., Palmero, A.M., Brito, M. del C., Núñez, J., Worsaae, K., 2009. Anchialine fauna of the Corona lava tube (Lanzarote, Canary Islands): diversity, endemism and distribution. Marine Biodiversity, 39, 169-182. https://doi.org/10.1007/s 12526-009-0023-6

Mejía-Ortíz, L.M., 2010. Pautas de comportamiento alimentario y adaptaciones progresivas en los apéndices auxiliares en Agostocaris bozanici y Barbouria yanezi (Crustacea: Decapoda: Caridea: Agostocarididae, Hyppolitidae). Revista Mexicana de Biodiversidad, 81, 193-201. https://doi.org/10.22201/ib.20078706e.2010.0.222

Mejía-Ortíz, L.M., Yañez, G., López-Mejía, M., 2017. Anchialocarididae, a new family of anchialine decapods and a new species of the genus Agostocaris from Cozumel Island, Mexico. Crustaceana, 90, 381-398. https://doi.org/10.1163/15685403-00003657

Palmer, R., 1985. The blue holes of the Bahamas. Jonathan Cape, London.

Pérez-Moreno, J.L., Iliffe, T.M., Bracken-Grissom, H.D., 2016. Life in the Underworld: Anchialine cave biology in the era of speleogenomics. International Journal of Speleology, 45, 149-170.

https://doi.org/10.5038/1827-806X.45.2.1954

Pesce, G.L., 1985. Cyclopids (Crustacea, Copepoda) from West Indian groundwater habitats. Bijdragen tot de Dierkunde, 55, 295-323.

https://doi.org/10.1163/26660644-05502009

Pesce, G.L., Iliffe, T.M., 2002. New records of cavedwelling mysids from the Bahamas and Mexico with description of Palaumysis bahamensis n. sp. (Crustacea: Mysidacea). Journal of Natural History, 36, 265-278. https://doi.org/10.1080/00222930010005033

Pettibone, M., 1985. Polychaete worms from a cave in the Bahamas and from experimental wood panels in deep water of the North Atlantic (Polynoidae, Macellicephalinae, Harmothoinae). Proceedings of the Biological Society of Washington, 98 127-149. 
Pleijel, F., Jondelius, U., Norlinder, E., Nygren, A., Oxelman, B., Schander, C., Sundberg, P., Thollesson, M., 2008. Phylogenies without roots? A plea for the use of vouchers in molecular phylogenetic studies. Molecular Phylogenetics and Evolution, 48, 369-371. https://doi.org/10.1016/j.ympev.2008.03.024

Rubio, F., Rolán, E., Worsaae, K., Martínez, A., Gonzalez, B.C., 2015. Description of the first anchialine gastropod from a Yucatán cenote, Teinostoma brankovitsi n. sp. (Caenogastropoda: Tornidae), including an emended generic diagnosis. Journal of Molluscan Studies, 82, 169-177. https://doi.org/10.1093/mollus/eyv049

Russ, A., Santos, S.R., Muir, C., 2010. Genetic population structure of an anchialine shrimp, Metabetaeus lohena (Crustacea: Alpheidae), in the Hawaiian Islands. Revista de Biología Tropical, 58, 159-170. https://doi.org/10.15517/rbt.v58i1.5201

Sánchez, N., Martínez, A., 2019. Dungeons and dragons: Two new species and records of Kinorhyncha from anchialine cenotes and marine lava tubes. Zoologischer Anzeiger, Fifth International Scalidophora Workshop 282, 161-175 https://doi.org/10.1016/j.jcz.2019.05.012

Santos, S.R., 2006. Patterns of genetic connectivity among anchialine habitats: a case study of the endemic Hawaiian shrimp Halocaridina rubra on the island of Hawaii. Molecular Ecology, 15, 2699-2718. https://doi.org/10.1111/j.1365-294X.2006.02965.x

Schlager, W., Austin, J.A., Corso, W., McNulty, C.L., Fluegel, E., Renz, O., Steinmetz, J.C., 1984. Early Cretaceous platform re-entrant and escarpment erosion in the Bahamas. Geology, 12, 147-150.

https://doi.org/10.1130/0091-7613(1984)12\% 3C147:ECPRAE\%3E2.0.CO;2

Schram, F.R., Yager, J., Emerson, M.J., 1986. Remipedia. Part I. Systematics. San Diego Society of Natural History Memoir, 15, 4-60.

Smart, P.L., Moseley, G.E., Richards, D.A., Whitaker, F.F., 2008. Past high sea-stands and platform stability: evidence from Conch Bar Cave, Middle Caicos. SEPN Core Workshop, p. 1-8. https://doi.org/10.2110/pec.08.22.0203

Stock, J.H., Iliffe, T.M., 1990. Amphipod crustaceans from anchihaline cave waters of the Galapagos Islands. Zoological Journal of the Linnean Society, 98, 141-160. https://doi.org/10.1111/j.1096-3642.1990.tb01213.x

Stock, J.H., Iliffe, T.M., Williams, D., 1986. The concept "anchialine" reconsidered. Stygologia, 2, 90-92.

Stock, J.H., Vermeulen, J.J., 1982. A representative of the mainly abyssal family Pardaliscidae (Crustacea, Amphipoda) in cave waters of the Caicos Islands. Bijdragen tot de Dierkunde, 52, 3-12.

https://doi.org/10.1163/26660644-05201002

Suárez-Morales, E., Cervantes-Martínez, A., GutiérrezAguirre, M.A., Iliffe, T.M., 2017a. A new Speleophria (Copepoda, Misophrioida) from an anchialine cave of the Yucatán Peninsula with comments on the biogeography of the genus. Bulletin of Marine Science, 93, 863-878. https://doi.org/10.5343/bms.2017.1012
Suárez-Morales, E., Gutiérrez-Aguirre, M.A., CervantesMartinez, A., Iliffe, T.M., 2017b. A new anchialine Stephos Scott from the Yucatan Peninsula with notes on the biogeography and diversity of the genus (Copepoda, Calanoida, Stephidae). ZooKeys, 1-17. https://doi.org/10.3897/zookeys.671.12052

Suárez-Morales, E., Iliffe, T.M., 1996. New superfamily of Calanoida (Copepoda) from an anchialine cave in the Bahamas. Journal of Crustacean Biology, 16, 754-762. https://doi.org/10.1163/193724096X00829

Trias, M., Ottenwalder, J.A., Jaume, D., 1997. Una campaña en la República Dominicana. Resultados preliminares. Endins, 21, 63-74.

van der Ham, J.L., 2002. Addition to the description of Spelaeonicippe provo (Amphipoda, Pardaliscidae). Crustaceana, 1271-1274. https://doi.org/10.1163/156854002321518199

Worsaae, K., 2014. Nerillidae Levinsen, 1883. In: Handbook of Zoology, Zoology Online. Degruyter.

Worsaae, K., 2005. Phylogeny of Nerillidae (Polychaeta, Annelida) as inferred from combined 18S rDNA and morphological data. Cladistics, 21, 143-162. https://doi.org/10.1111/j.1096-0031.2005.00058.x

Worsaae, K., Damsgaard Mikkelsen, M., Martínez, A., 2019a. Description of six new species of Mesonerilla (Nerillidae, Annelida) and an emended description of $M$. intermedia Wilke, 1953, from marine and cave environments. Marine Biodiversity, 49, 2141-2165. https://doi.org/10.1007/s12526-019-00984-6

Worsaae, K., Gonzalez, B.C., Kerbl, A., Nielsen, S.H., Jørgensen, J.T., Armenteros, M., Iliffe, T.M., Martinez, A., 2019b. Diversity and evolution of the stygobitic Speleonerilla nom. nov. (Nerillidae, Annelida) with description of three new species from anchialine caves in the Caribbean and Lanzarote. Marine Biodiversity, 49, 2167-2192. https://doi.org/10.1007/s12526-018-0906-5

Worsaae, K., Martínez, A., Núñez, J., 2009. Nerillidae (Annelida) from the Corona lava tube, Lanzarote, with description of Meganerilla cesari n. sp. Marine Biodiversity, 39, 195-207. https://doi.org/10.1007/s12526-009-0027-2

Worsaae, K., Sterrer, W., Iliffe, T.M., 2004. Longipalpa saltatrix, a new genus and species of the meiofaunal family Nerillidae (Annelida: Polychaeta) from an anchihaline cave in Bermuda. Proceedings of the Biological Society of Washington, 117, 346-362.

Yager, J., Schram, F., 1986. Lasionectes entrichoma, new genus, new species, (Crustacea: Remipedia) from anchialine caves in the Turks and Caicos, British West Indies. Proceedings of the Biological Society of Washington, 99, 65-70.

Zhang, Y., Sun, J., Rouse, G.W., Wiklund, H., Pleijel, F., Watanabe, H.K., Chen, C., Qian, P.-Y., Qiu, J.-W., 2018. Phylogeny, evolution and mitochondrial gene order rearrangement in scale worms (Aphroditiformia, Annelida). Molecular Phylogenetics and Evolution, 125, 220-231. https://doi.org/10.1016/j.ympev.2018.04.002 